\title{
Human genetics of meningococcal infections
}

\author{
Stephanie Hodeib ${ }^{1}$ Jethro A. Herberg ${ }^{1} \cdot$ Michael Levin $^{1} \cdot$ Vanessa Sancho-Shimizu $^{1,2}$ (])
}

Received: 16 November 2019 / Accepted: 2 February 2020 / Published online: 17 February 2020

(c) The Author(s) 2020

\begin{abstract}
Neisseria meningitidis is a leading cause of bacterial septicaemia and meningitis worldwide. Meningococcal disease is rare but can be life threatening with a tendency to affect children. Many studies have investigated the role of human genetics in predisposition to $N$. meningitidis infection. These have identified both rare single-gene mutations as well as more common polymorphisms associated with meningococcal disease susceptibility and severity. These findings provide clues to the pathogenesis of N. meningitidis, the basis of host susceptibility to infection and to the aetiology of severe disease. From the multiple discoveries of monogenic complement deficiencies to the associations of complement factor $\mathrm{H}$ and complement factor H-related three polymorphisms to meningococcal disease, the complement pathway is highlighted as being central to the genetic control of meningococcal disease. This review aims to summarise the current understanding of the host genetic basis of meningococcal disease with respect to the different stages of meningococcal infection.
\end{abstract}

\section{Introduction}

Neisseria meningitidis $(\mathrm{Nm})$ is a common commensal bacterium that is paradoxically also a devastating human pathogen. It is a Gram-negative diplococcus that selectively colonises the human nasopharynx (Stephens et al. 1983). $\mathrm{Nm}$ is encapsulated with a polysaccharide capsule which can be classified into 13 capsular serogroups known to cause disease. The six major serogroups typically associated with disease are serogroups A, B, C, Y, W, and X (Rosenstein et al. 2001; Xie et al. 2013). Carriage of $\mathrm{Nm}$ refers to the commensal colonisation of the bacterium in the human nasopharynx, whereas invasive meningococcal disease (IMD) is a result of bacterial invasion of the mucosal layer leading to its dissemination throughout the body causing meningitis and/or septicaemia, and may result in purpura fulminans and/or death (Coureuil et al. 2012; Lecuyer et al. 2017; Pace and Pollard 2012). Carriage rates vary depending on multiple variables including age, geographical location, and living conditions but is estimated at $10 \%$ in the

Vanessa Sancho-Shimizu

v.sancho-shimizu@imperial.ac.uk

1 Department of Paediatric Infectious Disease, Faculty of Medicine, Imperial College London, Norfolk Place, London W2 1PG, UK

2 Department of Virology, Faculty of Medicine, Imperial College London, Norfolk Place, London W2 1PG, UK general population (Cartwright et al. 1987; Caugant et al. 1992). Whilst majority of carriers remain asymptomatic or can develop low-grade bacteraemia, carriage of $\mathrm{Nm}$ leads to the production of protective antibodies and development of acquired immunity, and very rarely leads to invasive disease (Caugant and Maiden 2009; Goldschneider et al. 1969a; b; Pace and Pollard 2012). Incidence of IMD resulting in meningitis and septicaemia is estimated at $1-3$ cases per 100,000 individuals in Europe and North America (Parikh et al. 2018; Yazdankhah and Caugant 2004). However, in the "meningitis belt" of sub-Saharan Africa, attack rates during epidemics can reach 1000 cases per 100,000 individuals (Yazdankhah and Caugant 2004). The reasons for these regional differences in IMD rates are not fully understood; however, non-genetic environmental factors have been suggested to play a role (Agier et al. 2013; Omoleke et al. 2018). Young children are at particular risk of developing IMD due to the absence of protective antibodies. Whilst disease rates are high in those under 5 years of age, there are other peaks of IMD incidence seen in adolescents and in old age (Caugant and Maiden 2009; Cohn et al. 2013; Rosenstein et al. 2001). IMD is rare but it causes significant mortality at an overall rate of $10-15 \%$ with up to $19 \%$ of survivors suffering from severe life-long sequalae with a reduced quality of life (Cohn et al. 2013; Erickson and De Wals 1998; Kirsch et al. 1996; Pace and Pollard 2012).

Human genetics is known to influence response to pathogens. Nucleotide variants that alter or abolish the function of 
immune-related genes are important determinants of susceptibility to infection and course of disease (Casanova 2015a, b). Human genetic investigations are particularly pertinent to $\mathrm{Nm}$ infections as $\mathrm{Nm}$ is a human-host restricted pathogen resulting in a lack of suitable animal models. Due to this host restriction, it is anticipated that all evolutionary adaptations of the pathogen over time must be specific to human responses (Laver et al. 2015). Multiple genes have been identified via familial linkage, genome-wide association studies (GWASs), and candidate gene-based studies to influence the course of infection, elucidating the key pathways involved in IMD and the impact of the role of genetics (Brouwer et al. 2010; Casanova 2015b; Wright et al. 2009). A study of sibling risk ratio for IMD, comparing the risk of disease within family members to the general population, showed that host genetics contributed to approximately $30 \%$ of the total risk of developing disease (Haralambous et al. 2003). Monogenic disorders of the complement pathway have long been known to predispose to IMD (Westberg et al. 1995). Furthermore, GWASs for infection susceptibility are well established as a method for identification of more common polymorphisms for instance, polymorphisms of complement factor $\mathrm{H}(\mathrm{CFH})$ and complement factor $\mathrm{H}$-related 3 ( $C F H R 3$ ) have been associated with IMD, highlighting the host genetic contribution to disease (Davila et al. 2010; Martinon-Torres et al. 2016).

This review describes the role of human genetics with respect to the different stages of $\mathrm{Nm}$ infection. This includes the initial meningococcal colonisation of the human nasopharynx, followed by penetration of the mucosal membrane and invasion of the bloodstream, ultimately leading to systemic complications that can arise from an abnormal inflammatory and coagulation response. We have considered aspects of the immune system that are functionally related and grouped together in themed sections, whilst we acknowledge that these categorizations are not definitive and some genes may be involved in various stages of meningococcal pathogenesis. This review will summarise the contribution of host genetics at each phase of meningococcal infection highlighting the genes either associated with IMD or responsible for the monogenic disorders that determine IMD (Fig. 1).

\section{Colonisation}

$\mathrm{Nm}$ selectively colonises the epithelial surface of the nasopharynx. Initial adhesion is mediated by the meningococcal type IV pili and then further facilitated by interaction of its Opacity-associated adhesion (Opa) proteins with host cell surface proteins including carcino-embryonic antigen cell adhesion molecule (CEACAM) proteins found on the nasopharyngeal epithelium (Carbonnelle et al. 2006; Virji 2009;
Virji et al. 1996). Host colonisation is commonly asymptomatic; however, in some cases, colonisation can lead to invasion of the protective mucosa and entry of meningococci into the bloodstream, resulting in IMD (Aycock and Mueller 1950; Virji 2009). A candidate gene-based study found specific haplotypes in CEACAM 3 and CEACAM6 associated with IMD indicating that CEACAM proteins are key factors in initial meningococcal infection (Table 2) (Callaghan et al. 2008). A recent study reported a novel heterozygous mutation in short palate, lung, and nasal epithelial clone 1 (SPLUNC1, also known as BPIFA1) in three IMD cases (Table 1). This autosomal dominant SPLUNC1 mutation affected meningococcal biofilm formation, colonisation, and subsequent invasion, and is the first monogenic gene study demonstrating control of $\mathrm{Nm}$ colonisation (Mashbat et al. 2019).

Surfactant proteins are part of the collectins protein family involved in the innate immune system and in pathogen pattern recognition. They are expressed in the nasopharynx and respiratory tract and can activate inflammatory and phagocyte responses after binding to structures on the microbial cell wall (Pikaar et al. 1995). Surfactant proteins A1 and A2 (SP-A1 and SP-A2, respectively), encoded by SFTPA1 and SFTPA2, respectively, are expressed at the site of $\mathrm{Nm}$ colonisation. One candidate gene study has exhaustively investigated SP-A proteins in association with IMD describing various polymorphisms both increasing the risk of IMD and also showing a protective effect; however, these findings require further validation by other independent studies (Jack et al. 2006).

\section{Invasion}

Invasion of the nasopharyngeal epithelium leads to dissemination of the bacterium in the bloodstream. The mechanisms that lead to invasion are poorly understood; however, Goldschneider and colleagues in the late 1960s suggested that complement-dependent killing by antibody was a key defence against meningococcal infection, with high antibody titres seen later in life (Goldschneider et al. 1969a). The majority of the population does not develop severe disease, even in those who lack pre-existing bactericidal antibodies, suggesting that the innate immune response plays a key role in preventing invasive disease after meningococcal colonisation of the nasopharynx (Welsch and Granoff 2007). Defects in genes involved in this stage of invasion can provide gaps in host defence and give rise to IMD.

\section{Complement}

Complement plays an important role in the innate immune response, assisting in a rapid response against invading 


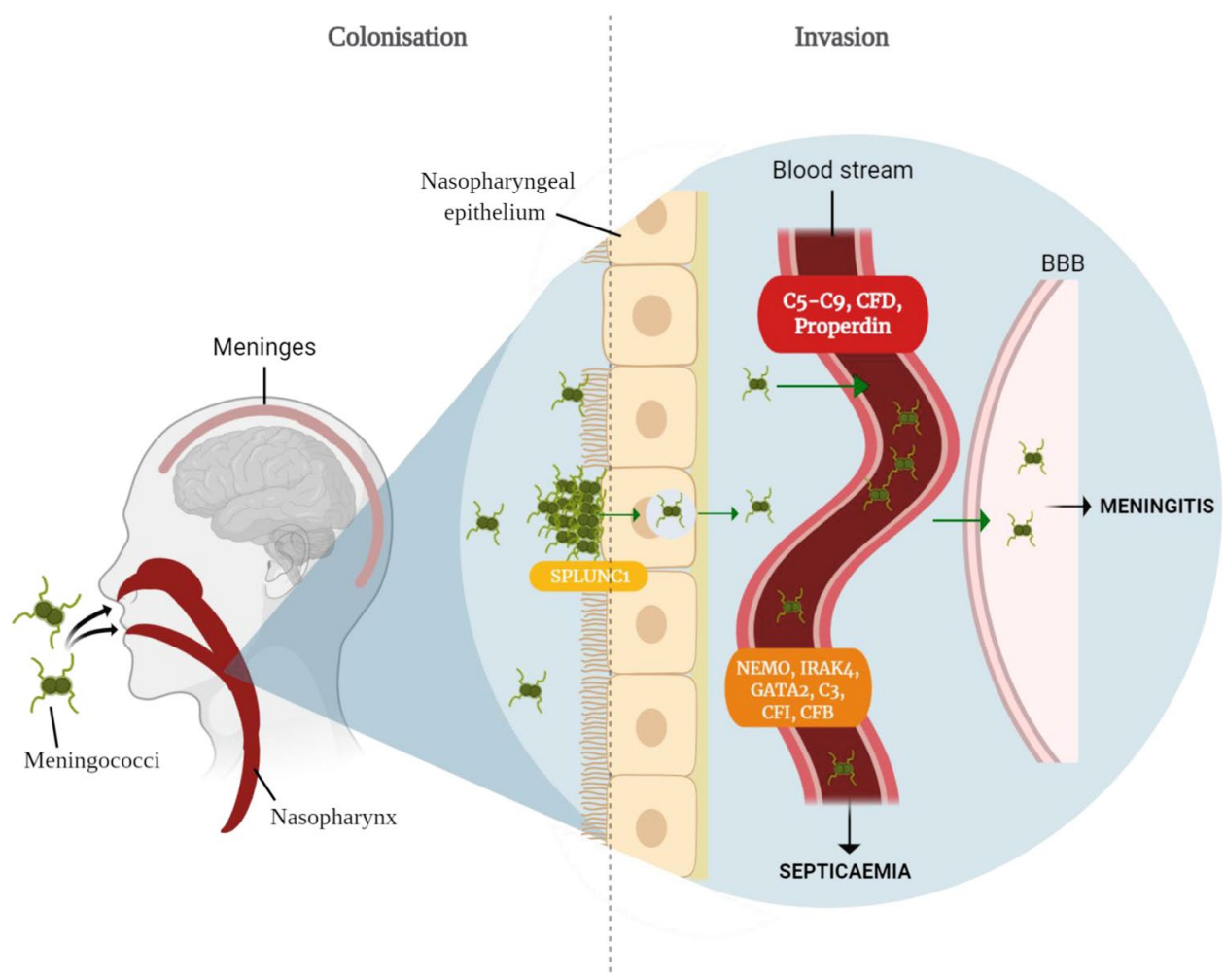

Fig. 1 Monogenic disorders underlying Neisseria meningitidis infection. $\mathrm{Nm}$ is transmitted via droplets and selectively colonises the human nasopharynx. In susceptible hosts, meningococci can invade and cross the nasopharyngeal mucosal epithelium to gain access to the blood stream. Once inside the bloodstream the meningococci grow in number and are disseminated throughout the host. Uncontrolled growth in the blood, leads to high titres of $\mathrm{Nm}$ and septicaemia. In other patients, there is less $\mathrm{Nm}$ replication in the blood, but meningococci breach the blood brain barrier (BBB), multiply uncon-

pathogens (Lewis and Ram 2014). Complement is activated via three main pathways which all involve complement component 3 (C3): the classical antibody-antigen interaction, the mannose-binding lectin (MBL) interaction with the microbial cell walls and finally, the alternative pathway activated by $\mathrm{C} 3$ interacting with complement Factor B (CFB) and complement Factor D (CFD) (Fig. 2) (Janeway et al. 2001). The alternative pathway can also act as an amplification loop for the other two pathways (Janeway et al. 2001). All three pathways feed into the same final pathway of the formation of $\mathrm{C} 3$ convertase enzyme that can produce complement component $\mathrm{C} 3 \mathrm{~b}$ which can act as an opsonin and facilitate phagocytosis by binding to the bacteria. $\mathrm{C} 3 \mathrm{~b}$ and $\mathrm{C} 3 \mathrm{can}$ also bind to form $\mathrm{C} 5$, generating $\mathrm{C} 5 \mathrm{~b}$ which leads to the formation of the membrane-attack complex (MAC), comprised of complement components $\mathrm{C} 5 \mathrm{~b}-\mathrm{C} 9$, creating pores in the membrane of the bacteria thereby causing bacterial death (Fig. 2) (Heesterbeek et al. 2019; Janeway et al. 2001). Host complement-dependent bactericidal activity is one of trollably in the cerebrospinal fluid and infect the meninges, leading to meningitis. The genes highlighted in red are monogenic disorders almost exclusively associated with IMD. Highlighted in orange, are monogenic disorders associated with bacterial infections and, though not exclusive to $\mathrm{Nm}$ infection, has been observed in cases of IMD. SPLUNC1, highlighted in yellow, has recently been demonstrated as a monogenic disorder associated with IMD though its pathogen exclusivity is unknown. Image created with biorender.com

the key protective immune responses against meningococcal infection and its role was established early at the start of the twentieth century (Flexner 1913; Flexner and Jobling 1908). Later, Goldschneider and colleagues were able to decisively elucidate the protective role of complement and antibodies against invasive $\mathrm{Nm}$ infection (Goldschneider et al. 1969a, b). The role of complement as a vital part of host defence against $N m$ infection has been unequivocally established and further supported by the increased susceptibility to infection by complement-deficient individuals described further below (Figueroa et al. 1993).

\section{Terminal complement deficiencies}

Functional deficiencies of the terminal complement (C5-C9) were one of the first characterised defects associated with IMD in the 1970s and 1980s, whereas the identification of mutations underlying these deficiencies came about later (Lim et al. 1976; Nagata et al. 1989; Petersen et al. 1976; 
Table 1 Monogenic disorders associated with meningococcal disease

\begin{tabular}{|c|c|c|c|c|c|c|c|}
\hline Gene & Variant & Inheritance & Study type & $\begin{array}{l}\text { Gene-specific } \\
\text { phenotype }\end{array}$ & $\begin{array}{l}\text { Infection } \\
\text { phenotype }\end{array}$ & $\begin{array}{l}\text { Disease } \\
\text { outcome }\end{array}$ & References \\
\hline \multicolumn{8}{|c|}{ COLONISATION } \\
\hline SPLUNC1 & c. $65 \mathrm{G}>$ A, p.G22E & $\mathrm{AD}$ & Familial & $\begin{array}{l}\text { Increased bacterial } \\
\text { adhesion }\end{array}$ & IMD & Susceptibility & Mashbat et al. (2019) \\
\hline \multicolumn{8}{|c|}{ INVASION } \\
\hline \multirow[t]{5}{*}{$C F P$} & c. $481 C>$ T, p.R161X & XR & Familial & $\begin{array}{l}\text { Reduced complement } \\
\text { function }\end{array}$ & IMD & Susceptibility & Westberg et al. (1995) \\
\hline & c. $1240 \mathrm{~T}>\mathrm{G}, \mathrm{p} . \mathrm{Y} 414 \mathrm{D}$ & XR & Familial & $\begin{array}{l}\text { Reduced complement } \\
\text { function }\end{array}$ & IMD & Susceptibility & $\begin{array}{l}\text { Fredrikson et al. } \\
\text { (1996) }\end{array}$ \\
\hline & c. $617 \mathrm{C}>\mathrm{G}, \mathrm{p} . \mathrm{S} 206 \mathrm{X}$ & XR & Familial & $\begin{array}{l}\text { Reduced complement } \\
\text { function }\end{array}$ & IMD & Susceptibility & $\begin{array}{l}\text { van den Bogaard et al. } \\
\text { (2000) }\end{array}$ \\
\hline & c. $893 \mathrm{G}>\mathrm{T}$ p.G298V & XR & Familial & $\begin{array}{l}\text { Reduced complement } \\
\text { function }\end{array}$ & IMD & Susceptibility & $\begin{array}{l}\text { van den Bogaard et al. } \\
\text { (2000) }\end{array}$ \\
\hline & c. $1164 \mathrm{G}>\mathrm{A}, \mathrm{p} . \mathrm{W} 388 \mathrm{X}$ & XR & Familial & $\begin{array}{l}\text { Reduced complement } \\
\text { function }\end{array}$ & IMD & Susceptibility & Helminen et al. (2012) \\
\hline \multirow[t]{5}{*}{ C5 } & c. $1055 \mathrm{~A}>\mathrm{G}, \mathrm{p} . \mathrm{Y} 352 \mathrm{C}$ & $\mathrm{AR}$ & Familial & $\begin{array}{l}\text { Reduced complement } \\
\text { function }\end{array}$ & IMD & Susceptibility & Marujo et al. (2019) \\
\hline & c. $754 \mathrm{G}>\mathrm{A}, \mathrm{p} . \mathrm{A} 252 \mathrm{~T}$ & $\mathrm{AR}$ & Familial & $\begin{array}{l}\text { Reduced complement } \\
\text { function }\end{array}$ & IMD & Susceptibility & Owen et al. (2015) \\
\hline & $\begin{array}{l}\text { c. } 55 \mathrm{C}>\mathrm{T}, \mathrm{p} . \mathrm{Q} 19 \mathrm{X} \\
\text { c. } 4444 \mathrm{C}>\mathrm{T}, \mathrm{p} . \mathrm{R} 1482 \mathrm{X}^{\mathrm{a}}\end{array}$ & $\mathrm{AR}$ & Familial & $\begin{array}{l}\text { Reduced complement } \\
\text { function }\end{array}$ & IMD & Susceptibility & Wang et al. (1995) \\
\hline & c. $1115 \mathrm{~A}>\mathrm{G}, \mathrm{p} . \mathrm{K} 372 \mathrm{R}$ & $\mathrm{AR}$ & Familial & $\begin{array}{l}\text { Reduced complement } \\
\text { function }\end{array}$ & IMD & Susceptibility & Pfarr et al. (2005) \\
\hline & $\begin{array}{l}\text { c. } 4890-4891 \text { delinsG, } \\
\text { p.L1631fs }\end{array}$ & $\mathrm{AR}$ & Familial & $\begin{array}{l}\text { Reduced complement } \\
\text { function }\end{array}$ & IMD & Susceptibility & $\begin{array}{l}\text { Delgado-Cervino et al. } \\
\text { (2005) }\end{array}$ \\
\hline \multirow[t]{5}{*}{ C6 } & c.878delA & $\mathrm{AR}$ & Familial & $\begin{array}{l}\text { Reduced complement } \\
\text { function }\end{array}$ & IMD & Susceptibility & Parham et al. (2007) \\
\hline & $\begin{array}{l}\text { c. } 1599 \mathrm{~T}>\mathrm{A}, \mathrm{p} . \mathrm{Y} 493 \mathrm{X} \\
\text { IVS3 + 3A >C }\end{array}$ & $\mathrm{AR}$ & Familial & $\begin{array}{l}\text { Reduced complement } \\
\text { function }\end{array}$ & IMD & Susceptibility & Parham et al. (2007) \\
\hline & c.1936delG & $\mathrm{AR}$ & Familial & $\begin{array}{l}\text { Reduced complement } \\
\text { function }\end{array}$ & IMD & Susceptibility & $\begin{array}{l}\text { Nishizaka et al. } \\
\text { (1996a) }\end{array}$ \\
\hline & c. $879 \mathrm{delG}$ & $\mathrm{AR}$ & Familial & $\begin{array}{l}\text { Reduced complement } \\
\text { function }\end{array}$ & IMD & Susceptibility & Hobart et al. (1998) \\
\hline & c. $1195 \mathrm{delC}$ & $\mathrm{AR}$ & Familial & $\begin{array}{l}\text { Reduced complement } \\
\text { function }\end{array}$ & IMD & Susceptibility & Zhu et al. (1998) \\
\hline \multirow[t]{6}{*}{$C 7$} & c. $2107 \mathrm{C}>\mathrm{T}$, p.Q681X & $\mathrm{AR}$ & Familial & $\begin{array}{l}\text { Reduced complement } \\
\text { function }\end{array}$ & IMD & Susceptibility & Barroso et al. (2010) \\
\hline & c. $2184 \mathrm{~T}>\mathrm{A}, \mathrm{p} . \mathrm{C} 728 \mathrm{X}$ & $\mathrm{AR}$ & Familial & $\begin{array}{l}\text { Reduced complement } \\
\text { function }\end{array}$ & IMD & Susceptibility & $\begin{array}{l}\text { Nishizaka et al. } \\
\text { (1996b) }\end{array}$ \\
\hline & $\begin{array}{l}\text { c. } 281-1 \mathrm{G}>\mathrm{T} \\
\text { c. } 1-?-2350+? \mathrm{del}\end{array}$ & $\mathrm{AR}$ & Familial & $\begin{array}{l}\text { Reduced complement } \\
\text { function }\end{array}$ & IMD & Susceptibility & Ki et al. (2005) \\
\hline & c. $1135 \mathrm{G}>\mathrm{C}, \mathrm{p} . \mathrm{G} 379 \mathrm{R}$ & $\mathrm{AR}$ & Familial & $\begin{array}{l}\text { Reduced complement } \\
\text { function }\end{array}$ & IMD & Susceptibility & Fernie et al. (1997) \\
\hline & c.1922delAG & $\mathrm{AR}$ & Familial & $\begin{array}{l}\text { Reduced complement } \\
\text { function }\end{array}$ & IMD & Susceptibility & Barroso et al. (2004) \\
\hline & $\begin{array}{l}\text { c.633_643del } \\
\text { c. } 1922 \mathrm{del} \mathrm{AG}^{\mathrm{a}}\end{array}$ & $\mathrm{AR}$ & Familial & $\begin{array}{l}\text { Reduced complement } \\
\text { function }\end{array}$ & IMD & Susceptibility & Barroso et al. (2006) \\
\hline \multirow[t]{2}{*}{$C 8 B$} & c. $1282 \mathrm{C}>\mathrm{T}, \mathrm{p} . \mathrm{R} 428 \mathrm{X}$ & $\mathrm{AR}$ & Familial & $\begin{array}{l}\text { Reduced complement } \\
\text { function }\end{array}$ & IMD & Susceptibility & $\begin{array}{l}\text { Dellepiane et al. } \\
\text { (2016) }\end{array}$ \\
\hline & $\begin{array}{l}\text { c. } 271 \mathrm{C}>\mathrm{T}, \mathrm{p} . \mathrm{Q} 91 \mathrm{X} ; \\
\text { c. } 820 \mathrm{C}>\mathrm{T}, \mathrm{p} . \mathrm{R} 274 \mathrm{X}\end{array}$ & AR & Familial & $\begin{array}{l}\text { Reduced complement } \\
\text { function }\end{array}$ & IMD & Susceptibility & Saucedo et al. (1995) \\
\hline
\end{tabular}


Table 1 (continued)

\begin{tabular}{|c|c|c|c|c|c|c|c|}
\hline Gene & Variant & Inheritance & Study type & $\begin{array}{l}\text { Gene-specific } \\
\text { phenotype }\end{array}$ & $\begin{array}{l}\text { Infection } \\
\text { phenotype }\end{array}$ & $\begin{array}{l}\text { Disease } \\
\text { outcome }\end{array}$ & References \\
\hline & $\begin{array}{l}\text { c.1041_1047dup, } \\
\text { p.L350fs } \\
\text { c.271C > T, p.Q91X }\end{array}$ & $\mathrm{AR}$ & Familial & $\begin{array}{l}\text { Reduced complement } \\
\text { function }\end{array}$ & IMD & Susceptibility & Arnold et al. (2009) \\
\hline \multirow[t]{2}{*}{ C9 } & c. $346 C>$ T, p.R116X & $\mathrm{AR}$ & Cohort & $\begin{array}{l}\text { Reduced complement } \\
\text { function }\end{array}$ & MM & Susceptibility & Kira et al. (1998) \\
\hline & c. $162 \mathrm{C}>\mathrm{A}, \mathrm{p} . \mathrm{C} 54 \mathrm{X}$ & $\mathrm{AR}$ & Familial & $\begin{array}{l}\text { Reduced complement } \\
\text { function }\end{array}$ & IMD & Susceptibility & Zoppi et al. (1990) \\
\hline \multirow[t]{4}{*}{$C F D$} & $\begin{array}{r}\text { c. } 638 \mathrm{~T}>\text { G, p.V213G; } \\
\text { c. } 640 \mathrm{~T}>\text { C, p.C214R }\end{array}$ & $\mathrm{AR}$ & Familial & $\begin{array}{l}\text { Reduced complement } \\
\text { function }\end{array}$ & MS & Susceptibility & Sprong et al. (2006) \\
\hline & c. $125 \mathrm{C}>\mathrm{A}, \mathrm{p} . \mathrm{S} 42 \mathrm{X}$ & $\mathrm{AR}$ & Familial & $\begin{array}{l}\text { Reduced complement } \\
\text { function }\end{array}$ & IMD & Susceptibility & Biesma et al. (2001) \\
\hline & c.620G > C, p.R176P & $\mathrm{AR}$ & Familial & $\begin{array}{l}\text { Reduced complement } \\
\text { function }\end{array}$ & IMD & Susceptibility & Sng et al. (2018) \\
\hline & $\begin{array}{l}\text { c. } .677-678 \text { delinsTTCT } \\
\text { c. } 653 \mathrm{~T}>\mathrm{C}, \text { p.L218P }\end{array}$ & $\mathrm{AR}$ & Familial & $\begin{array}{l}\text { Reduced complement } \\
\text { function }\end{array}$ & IMD & Susceptibility & El Sissy et al. (2019) \\
\hline$C F B$ & $\begin{array}{l}\text { c.766C > T, p.Q256X } \\
\text { c. } 1894-1897 \text { delTTTG, } \\
\text { p.F632CfsX8 }{ }^{\mathrm{a}}\end{array}$ & $\mathrm{AR}$ & Familial & $\begin{array}{l}\text { Reduced complement } \\
\text { function }\end{array}$ & MM & Susceptibility & Slade et al. (2013) \\
\hline \multirow[t]{5}{*}{$C F I$} & c. $1282 \mathrm{~A}>\mathrm{T}$ p.H400L & $\mathrm{AR}$ & Familial & $\begin{array}{l}\text { Reduced complement } \\
\text { function }\end{array}$ & IMD & Susceptibility & Vyse et al. (1996) \\
\hline & $\begin{array}{l}\text { c. } 1282 \mathrm{~A}>\mathrm{T} \text { p.H400L } \\
\text { c. } 801 \mathrm{G}>\mathrm{A} \text { p.del-exon } 5^{\mathrm{a}}\end{array}$ & $\mathrm{AR}$ & Familial & $\begin{array}{l}\text { Reduced complement } \\
\text { function }\end{array}$ & IMD & Susceptibility & Vyse et al. (1996) \\
\hline & $\begin{array}{l}\text { c.266_?_536+?del } \\
\text { c.1420C > T, p.R474XX }\end{array}$ & $\mathrm{AR}$ & Familial & $\begin{array}{l}\text { Reduced complement } \\
\text { function }\end{array}$ & IMD & Susceptibility & $\begin{array}{l}\text { Alba-Dominguez et al. } \\
\text { (2012) }\end{array}$ \\
\hline & $\begin{array}{l}\text { c. } 485 \mathrm{G}>\mathrm{A}, \mathrm{p} . \mathrm{G} 162 \mathrm{D} \\
\text { c. } 1176 \_1177 \text { dupAT, } \\
\text { p.W393Yfs*5 }\end{array}$ & $\mathrm{AR}$ & Familial & $\begin{array}{l}\text { Reduced complement } \\
\text { function }\end{array}$ & IMD & Susceptibility & $\begin{array}{l}\text { Alba-Dominguez et al. } \\
\text { (2012) }\end{array}$ \\
\hline & c. $772 \mathrm{G}>\mathrm{A}, \mathrm{p} . \mathrm{A} 258 \mathrm{~T}$ & $\mathrm{AR}$ & Familial & $\begin{array}{l}\text { Reduced complement } \\
\text { function }\end{array}$ & IMD & Susceptibility & $\begin{array}{l}\text { Alba-Dominguez et al. } \\
\text { (2012) }\end{array}$ \\
\hline C3 & c. $1716 \mathrm{G}>\mathrm{A}, \mathrm{p} . \mathrm{K} 552 \mathrm{X}$ & $\mathrm{AR}$ & Familial & $\begin{array}{l}\text { Reduced complement } \\
\text { function }\end{array}$ & IMD & Susceptibility & $\begin{array}{l}\text { Da Silva Reis et al. } \\
\text { (2002) }\end{array}$ \\
\hline$C 2$ & c.841_868del, p.Val281fs & $A R$ & Cohort & $\begin{array}{l}\text { Reduced complement } \\
\text { function }\end{array}$ & IMD & Susceptibility & Jonsson et al. (2005) \\
\hline \multicolumn{8}{|c|}{ INFLAMMATORY RESPONSE } \\
\hline IRAK4 & c.877C > T, p.Q293X & $\mathrm{AR}$ & Case study & $\begin{array}{l}\text { Impaired IL-6 } \\
\text { production }\end{array}$ & IMD & Susceptibility & Frans et al. (2015) \\
\hline$I K B K G$ & c. $1249 \mathrm{~T}>\mathrm{C}, \mathrm{p} . \mathrm{C} 417 \mathrm{R}$ & $\mathrm{XR}$ & Case study & N/A & IMD & Susceptibility & $\begin{array}{l}\text { Huppmann et al. } \\
\text { (2015) }\end{array}$ \\
\hline GATA2 & c. $988 \mathrm{C}>\mathrm{T}$, p.R330X & N/A & Cohort & N/A & IMD & N/A & Spinner et al. (2014) \\
\hline
\end{tabular}

$I M D$ invasive meningococcal disease, $M S$ meningococcal septicaemia, $M M$ meningococcal meningitis, $A D$ autosomal dominant, $X R$ X-linked recessive, $A R$ autosomal recessive

${ }^{a}$ Compound heterozygous mutations

Snyderman et al. 1979). Complement deficiencies can be acquired or inherited, the latter being rarer occurring in $0.03 \%$ of the general population with frequencies depending on complement component and ethnicity (Lewis and Ram 2014). Mutations in any one of the terminal complement genes ( $C 5, C 6, C 7, C 8 A, C 8 B$, or $C 9)$ result in an autosomal recessive monogenic disorder leading to impaired function of the complement system and increased susceptibility to $\mathrm{Nm}$ infection (Table 1) (Arnold et al. 2009; Barraso et al. 2004, 2006, 2010; Delgado-Cervino et al. 2005; Dellepiane 
Fig. 2 Complement pathway. Overview of three main complement pathways that involves multiple cleavage events that converge to a cleavage of central component $\mathrm{C} 3-\mathrm{C} 3 \mathrm{~b}$, which triggers a cascade that leads to the formation of the membraneattack complex capable of cell lysis via pore formation. $\mathrm{C} 3 \mathrm{~b}$ is also an opsonin capable of tagging pathogens for phagocytosis and $\mathrm{C} 3 \mathrm{~b}$ formation can act as a positive feedback loop for the alternative pathway, necessitating the need for several negative regulators including CFI, and $\mathrm{CFH}$. Properdin is a positive regulator of the alternative pathway, stabilising the $\mathrm{C} 3$ convertase. Those in red symbolises factors that have reported loss of function mutations that are associated with either chronic meningococcaemia or IMD. Image created with biorender.com

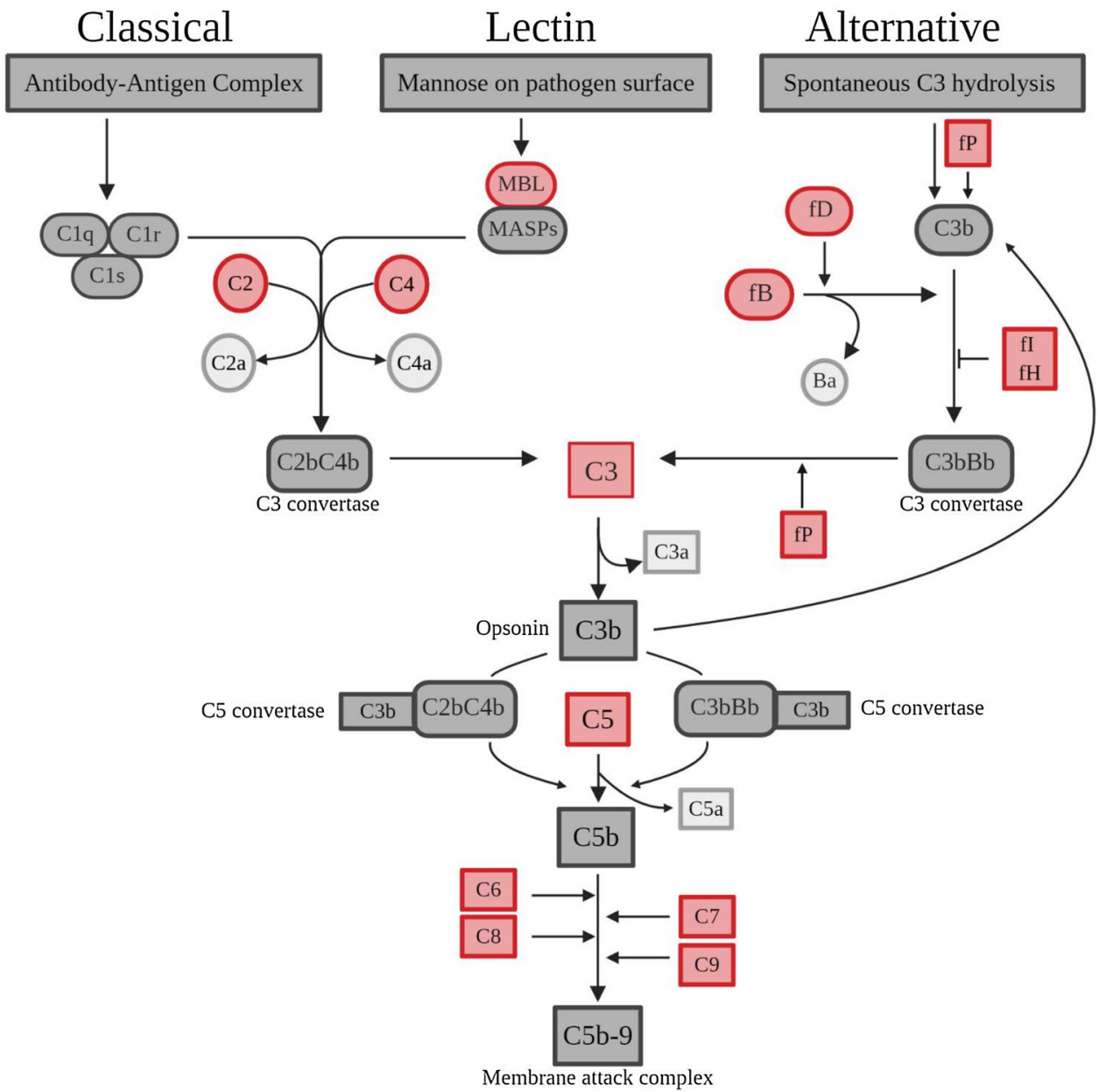

et al. 2016; Fernie et al. 1997; Figueroa et al. 1993; Hobart et al. 1998; Kaufmann et al. 1993; Ki et al. 2005; Kira et al. 1998; Kojima et al. 1998; Lee et al. 1978; Lewis and Ram 2014; Marujo et al. 2019; Nishizaka et al. 1996a, b; Owen et al. 2015; Parham et al. 2007; Pfarr et al. 2005; Platonov et al. 1993; Saucedo et al. 1995; Wang et al. 1995; Wurzner et al. 1995; Zhu et al. 1998; Zoppi et al. 1990). Patients with deficiencies of the terminal complement are characteristically distinct as they typically present with recurrent meningococcal infection, with lower mortality rates per episode (Figueroa and Densen 1991; Fijen et al. 1999; Platonov et al. 1993).

\section{Alternative pathway complement factors}

Functional deficiencies of all the alternate pathway factors have been associated with IMD. Properdin is a positive regulator of the alternative complement pathway by binding to and stabilising $\mathrm{C} 3 \mathrm{~b}$, prolonging its half-life and functional activity, as well as functioning as an initiator of the alternative pathway (Lewis and Ram 2014). Functional properdin deficiency resulting in impaired complement response and reduced bactericidal activity was first associated with IMD in a multiplex kindred in the 1980s (Braconier et al. 1983; Cunliffe et al. 1995; Densen et al. 1987; Figueroa and Densen 1991; Fijen et al. 1989; Genel et al. 2006; Nielsen and Koch 1987; Nielsen et al. 1989; Ross and Densen 1984; Schlesinger et al. 1990, 1993; Sjoholm et al. 1982; Spath et al. 1999). Genetic deficiency of properdin, encoded by $C F P$, is an $\mathrm{X}$-linked recessive disorder and is typically associated with non-recurrent and rapidly progressive fatal meningococcaemia (Table 1) (Fredrikson et al. 1996; Helminen et al. 2012; Sjoholm et al. 1982; Spath et al. 1999; van den Bogaard et al. 2000; Westberg et al. 1995). In properdin-deficient patients, around $50 \%$ of IMD is caused by uncommon serogroups of $\mathrm{Nm}$ such as W and Y (Figueroa and Densen 1991). Functional deficiency of complement factor D (CFD) was first reported in a patient with recurrent $\mathrm{Nm}$ infections (Hiemstra et al. 1989). The discovery of mutations in $C F D$ resulting in an autosomal recessive disorder predisposing to IMD was subsequently reported in other unrelated kindreds (Table 1) (Biesma et al. 2001; El Sissy et al. 2019; Sng et al. 2018; Sprong et al. 2006). There has been one report 
of autosomal recessive complement Factor B (CFB) deficiency with recurrent pneumococcal and meningococcal infections (Table 1) (Slade et al. 2013). Complement Factor I (CFI) is a negative regulator of the alternative pathway that proteolytically inactivates $\mathrm{C} 3 \mathrm{~b}$. CFI deficiency results in uncontrolled continuous activation of the alternative pathway and is associated with recurrent infections from encapsulated bacteria (Alba-Dominguez et al. 2012). In the 1990s, a study suggested CFI deficiency, resulting from recessive mutations, to be responsible for two cases of recurrent pyogenic infections, including $\mathrm{Nm}$ infection (Vyse et al. 1996). More recently several patients with autosomal recessive CFI deficiency have been associated with IMD (Table 1) (Alba-Dominguez et al. 2012).

Finally, GWASs have identified polymorphisms in a broad region spanning complement factor $\mathrm{H}(\mathrm{CFH})$ and complement factor H-related $3(\mathrm{CFHR} 3)$ as highly significantly associated with IMD (Table 2) (Davila et al. 2010; Martinon-Torres et al. 2016). This association has been validated in different cohorts and represents the most significant genetic association with susceptibility to IMD (Table 2) (Bradley et al. 2015; Davila et al. 2010; Haralambous et al. 2006; Martinon-Torres et al. 2016). CFH acts as a negative regulator and competes with $\mathrm{CFB}$ resulting in inactive $\mathrm{C} 3 \mathrm{~b}$ (Fig. 2) (Janeway et al. 2001).

The mechanisms underlying the association of polymorphisms in the $C F H / C F H R 3$ region with IMD have begun to be clarified. $\mathrm{Nm}$ expresses a factor $\mathrm{H}$-binding protein (fHBP) on its surface which binds human $\mathrm{CFH}$. This binding assists the bacteria in evading complement-mediated killing in the blood stream (Schneider et al. 2009). CFHR proteins, which have partial homology to $\mathrm{CFH}$, can antagonise the immune evasion through competition for fHBP binding (Caesar et al. 2014). However, the plasma concentrations of the CFHR proteins are low compared to that of CFH (Pouw et al. 2016), and patients with deletions in the $C F H R$ region are not at increased risk of IMD (Davila et al. 2010). Therefore, other mechanisms are likely to contribute to the association of the $C F H / C F H R 3$ region with IMD (Caesar et al. 2014). The EUCLIDS consortium (Martinon-Torres et al. 2018) is currently exploring the role of genetic polymorphisms in the $C F H / C F H R 3$ region in determining $\mathrm{CFH}$ plasma concentrations.

\section{Early complement components}

Deficiencies of the early complement components, $\mathrm{C} 1, \mathrm{C} 2$, and $\mathrm{C} 4$, are inherited in an autosomal recessive manner and classically associated with autoimmune diseases, particularly systemic lupus erythematosus (SLE), although the impact on $\mathrm{Nm}$ infection is controversial (Fijen et al. 1989; Macedo and Isaac 2016; Tebruegge and Curtis 2008). The role of the $\mathrm{C} 4$ isoforms $(\mathrm{C} 4 \mathrm{~A}$ and $\mathrm{C} 4 \mathrm{~B})$ in $\mathrm{Nm}$ infection is conflicting with reports that $\mathrm{C} 4$ deficiency alone is not significant enough to predispose individuals to bacterial infection (Bishof et al. 1990; Cates et al. 1992; Fasano et al. 1990). Until 1991, only six cases of C2 deficiency with incidence of IMD were reported (Figueroa and Densen 1991). Since then, few cases of IMD patients with C2 deficiency have been reported including a 4-year-old child from England, a 12-year-old child suffering from primary meningococcal arthritis as a result of $\mathrm{Nm}$ serogroup $\mathrm{Y}$ infection, and three patients from Sweden with homozygous C2 deficiency (Hoare et al. 2002; Hussain et al. 2007; Jonsson et al. 2005). Primary C3 deficiencies are rare, most likely due to the central role, it plays in the complement response, but these patients can suffer from recurrent bacterial infections, including from $\mathrm{Nm}$ (Da Silva Reis et al. 2002).

\section{Mannose-binding lectin}

MBL is a collectin, encoded by $M B L 2$, that can recognise $\mathrm{Nm}$ and trigger the complement cascade by forming a complex and binding mannose residues present on pathogen surfaces (Janeway et al. 2001). In a candidate gene study, three functional variants in codon 52, 54, and 56 of MBL2 exon 1 show reduced plasma protein concentrations and have been previously associated with IMD (Table 2) (Hibberd et al. 1999). MBL2 polymorphisms were also found to be significantly associated with IMD in a paediatric cohort with IMD incidence increasing with younger age (Faber et al. 2007); however, in a subsequent study, these polymorphisms were found to have no significant association with IMD (Lundbo et al. 2015). No association was also found between low serum MBL concentrations and serogroup B/C IMD in a Norwegian cohort (Garred et al. 1993).

\section{Inflammatory response}

The proper induction of the immune response including activation of immune cells and cytokines following infection is critical for preventing IMD as is demonstrated by the description of IMD in a patient with a mutation in GATA2, a hematopoietic transcription factor, resulting in cytopenias and associated with viral and bacterial infections and malignancies (Table 1) (Spinner et al. 2014). Cytokine production is regulated by a complex system involving multiple factors and mediators (Westendorp et al. 1997). Some mutations can dysregulate this process and the immunological phenotype can vary. IRAK4 and NEMO deficiencies result in reduced cytokine levels including an abolished IL-6 response (Picard et al. 2011; von Bernuth et al. 2008). Conversely, some variants of $I L I B$ and $T N F$, can result in an excessive inflammatory response that can increase risk of developing severe disease and even death in meningococcal infection (Nadel et al. 


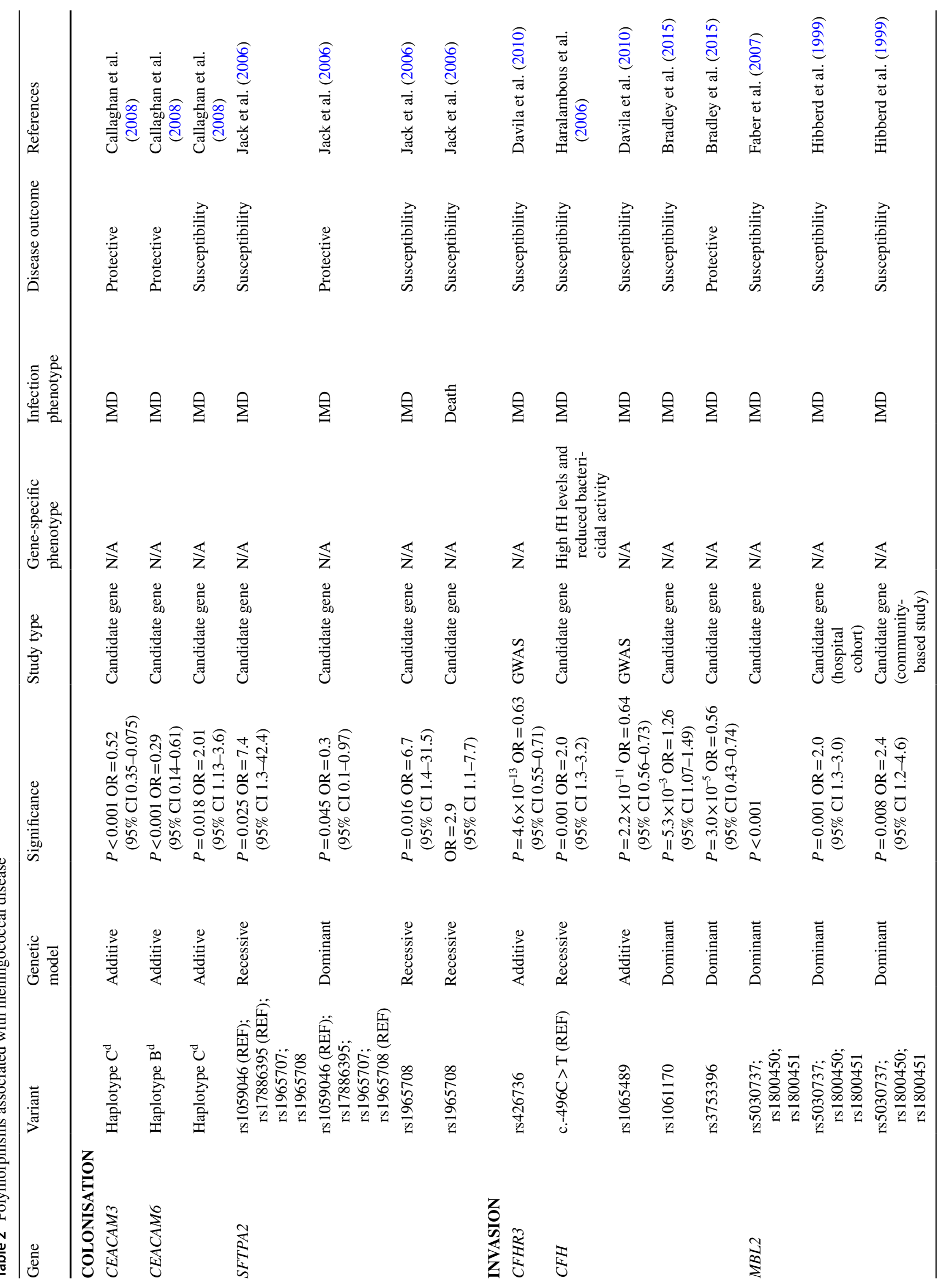




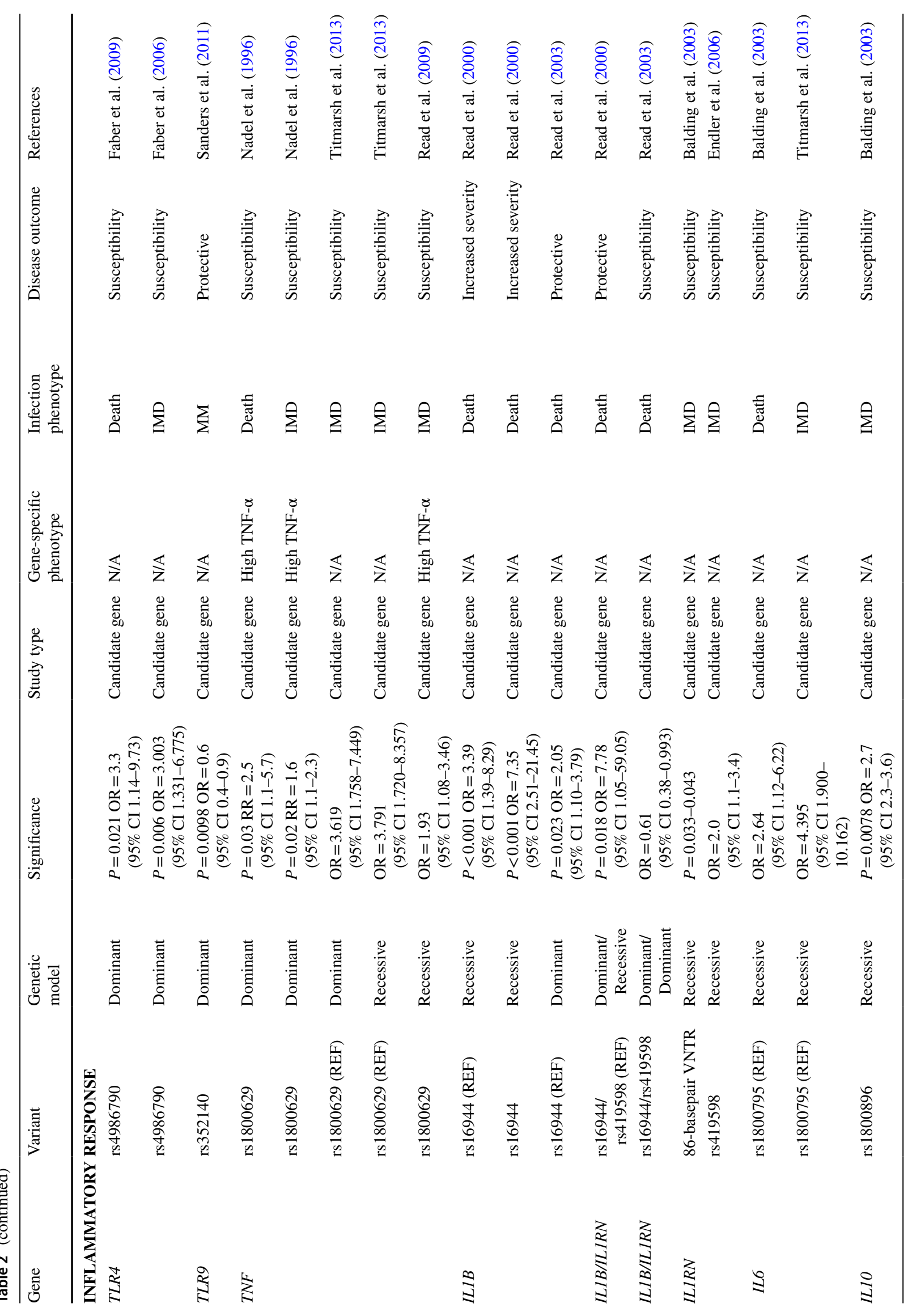




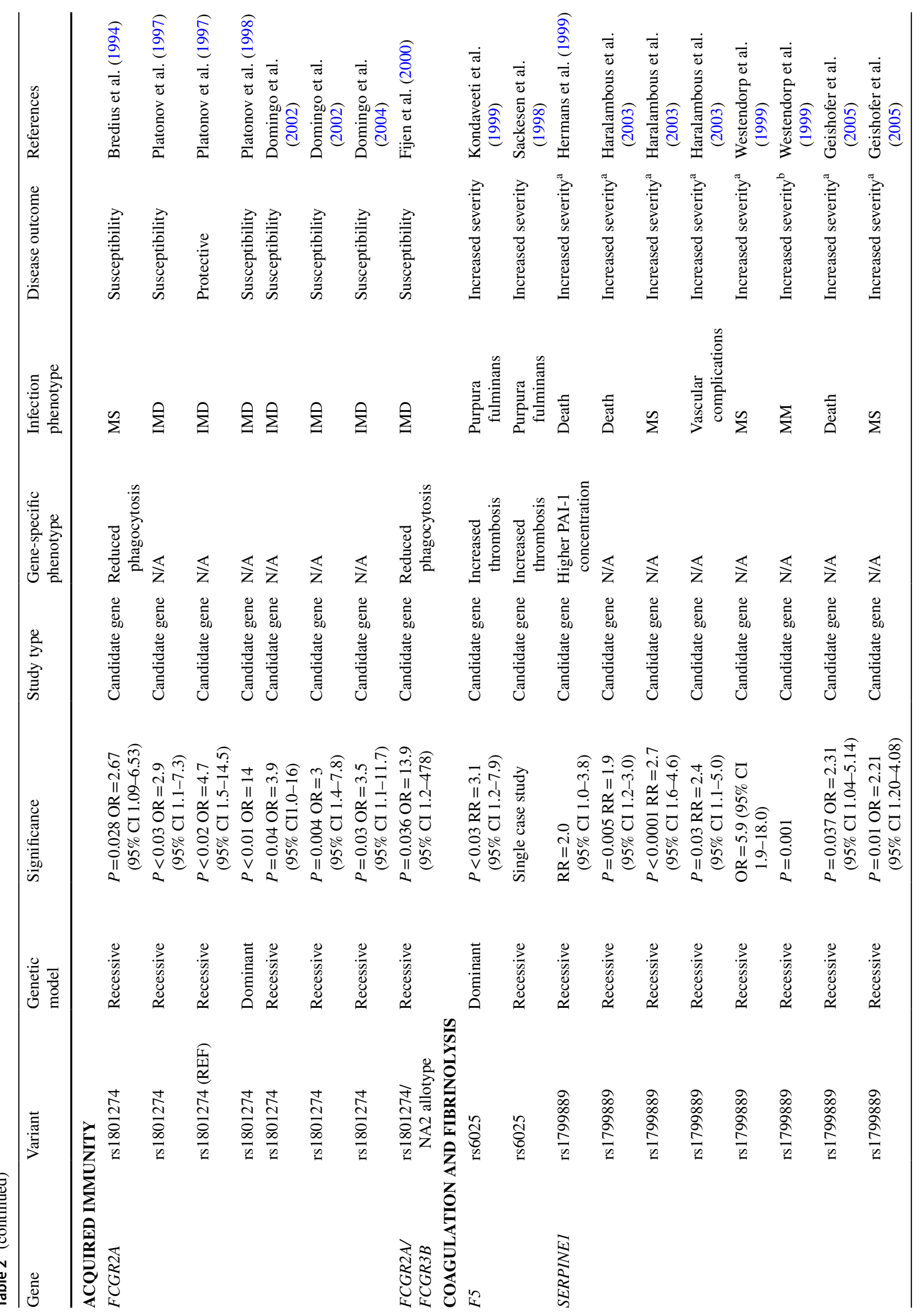




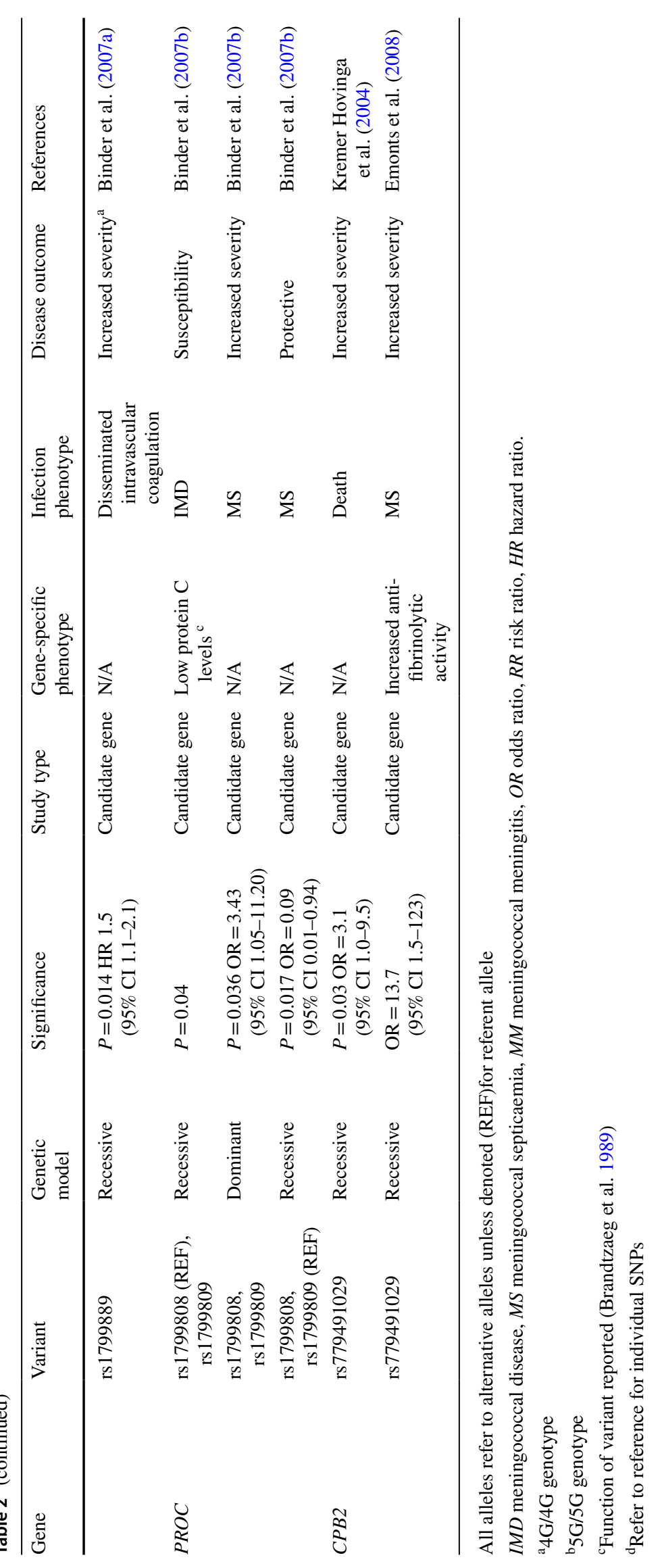


1996; Read et al. 2000, 2003). Key cytokines in IMD include the pro-inflammatory cytokines interleukin-1-beta (IL-1 ), interleukin-6 (IL-6), tumour necrosis factor-alpha (TNF- $\alpha$ ), and the anti-inflammatory cytokines IL-10 and IL-1 receptor antagonist (IL-1Ra) (Hackett et al. 2001; Pathan et al. 2003). These key cytokines have been investigated in candidate gene studies in relevance to IMD.

\section{Toll-like receptors}

The toll-like receptor (TLR) signalling pathway is a central part of the innate immune response as it recognises pathogens, triggering a signalling cascade that ends in production of cytokines and chemokines (Kawai and Akira 2011). Genetic deficiencies of key mediators of the innate immune response, autosomal recessive IRAK4, and X-linked recessive $I K B K G$ (encoding for NEMO) deficiencies, underlie pyogenic bacterial infection with impaired interleukin-6 (IL6) production and $\mathrm{C}$-reactive protein $(\mathrm{CRP})$ production $(\mathrm{Ku}$ et al. 2007; Picard et al. 2003, 2011). Deficiencies in these proteins are associated with impaired canonical TLR signalling pathway and typically predispose to pyogenic bacterial infections; however, cases of IMD have also been observed (Frans et al. 2015; Huppmann et al. 2015; Picard et al. 2010, 2011). Other polymorphisms associated with IMD have been identified in specific TLRs, including TLR4 and TLR9. TLR4 is a major transmembrane receptor expressed in immune cells and recognises bacterial lipopolysaccharides (LPS), a major outer membrane component of Gram-negative bacteria including $\mathrm{Nm}$ (Kawai and Akira 2011). Binding of LPS to the TLR4 complex initiates a signalling cascade leading to the activation of NF- $\mathrm{kB}$-mediated transcription and production of pro-inflammatory cytokines (TNF, IL6, IL1 etc.) (Kawai and Akira 2011). A candidate gene-based study found an excess of rare heterozygous missense mutations in TLR4 in a cohort of patients with IMD (Smirnova et al. 2003). A TLR4 polymorphism, (rs4986790), results in hyporesponsiveness to LPS (Arbour et al. 2000) which has been associated with IMD, and mortality (Table 2) (Faber et al. 2006, 2009), with conflicting findings (Biebl et al. 2009; Read et al. 2001). A candidate gene study-associated polymorphisms in TLR9, an intracellular, endosomal, receptor that recognises unmethylated $\mathrm{CpG}$ motifs in bacterial DNA, with meningococcal meningitis in a large paediatric cohort (Table 2) (Kawai and Akira 2011; Sanders et al. 2011).

\section{Cytokine response}

TNF- $\alpha$ is central to the activation of the inflammatory response, it mediates septicaemia and septic shock and circulating TNF- $\alpha$ is correlated to severity, and mortality, in IMD (Waage et al. 1987). Possession of the rare $T N F$ allele, resulting from a single nucleotide polymorphism (SNP) in the promoter region (rs1800629), was shown to increase constitutive and inducible secreted TNF- $\alpha$ and may predispose to susceptibility and severity to $\mathrm{Nm}$ infection (Table 2) (Nadel et al. 1996; Read et al. 2009). However, another study has reported that it is the referent GG genotype that increases risk of IMD (Table 2) (Titmarsh et al. 2013) whereas other studies report no association between $T N F$ and IMD (Balding et al. 2003; Domingo et al. 2004; Read et al. 2000), showing that these results have not been reproducible and more work is needed to determine its effect. IL-6 is secreted by macrophages and $\mathrm{T}$ cells and has pro-coagulant effects that assist in the regulation of the immune response and haematopoiesis (Tanaka et al. 2014). High levels of circulating IL-6 are associated with poor outcome in meningococcal septic shock and septicaemia (Hack et al. 1989; Waage et al. 1989). A particular SNP in $I L-6$ (rs1800795) has been associated with an increased risk of death in IMD (Table 2) (Balding et al. 2003; Titmarsh et al. 2013). IL-10 is an anti-inflammatory cytokine that suppresses the inflammatory response, upregulates IL-1Ra, and downregulates other pro-inflammatory cytokines. A SNP in $I L-10$ (rs1800896) has been significantly correlated with severe disease in IMD (Table 2) (Balding et al. 2003).

IL- $1 \alpha$ and IL- $1 \beta$ are pro-inflammatory cytokines, produced mainly by macrophages and monocytes that binds to the IL-1 receptor (IL-1R) complex and activates the acute phase response. IL-1Ra, encoded by $I L-1 R N$, can also compete with the binding of IL- $1 \alpha$ and IL-1 $\beta$ to the IL-1R complex. Increased levels of IL-1 $\beta$ and IL-1Ra have been associated with IMD. Allelic variation at the IL-1 gene cluster affects the inflammatory response and course of infection (Read et al. 2003). A SNP in $I L 1 B$ (rs16944) has been associated with an increased risk of death in homozygous individuals (Table 2) (Read et al. 2000, 2003). Furthermore, the presence of the heterozygous $I L 1 B$ (rs 16944) polymorphism combined with the homozygous $I L-1 R N$ (rs419598) polymorphism is also associated with outcome of IMD (Table 2) (Read et al. 2000, 2003). However, another study described no association between the ILIB (rs16944) polymorphism and IMD outcome but showed that IMD outcome was associated with the ILIRN homozygous (rs419598) polymorphism (Table 2) (Endler et al. 2006). An 86 base pair variable number tandem repeat (VNTR) in intron 2 of $I L I R N$ has also been associated with mortality and severe septicaemia in IMD patients (Table 2) (Balding et al. 2003).

\section{Acquired immunity}

$\mathrm{Fc}$ receptors for $\operatorname{IgG}(\mathrm{Fc} \gamma \mathrm{R})$ are found on phagocytes and are a central component for phagocytosis. Three subclasses of FcyRs exhibit biallelic polymorphisms that influence the IgG-binding efficiency. Fc $\gamma$ RIIa, Fc $\gamma$ RIIIa, and Fc $\gamma$ RIIIb, encoded by FCGR2A, FCGR3A, and FCGR3B, respectively, 
are shown to be important against meningococcal infection (Fijen et al. 2000; van der Pol et al. 2001). FcyRIIa is expressed on poly-morphonuclear cells and is the only subclass that can bind IgG2 (van der Pol et al. 2001). There are two Fc $\gamma$ RIIa allotypes determined by rs 1801274 (p.H131R), in humans the allotype Fc $\gamma \mathrm{RIIa}-\mathrm{H} / \mathrm{H} 131$ is more effective at IgG2-mediated phagocytosis of encapsulated bacteria (Sanders et al. 1995). Multiple candidate gene studies have shown correlation of the FCGR2A rs 1801274 (p.H131R) polymorphism in development of severe IMD in patients (Table 2) (Bredius et al. 1994; Domingo et al. 2002, 2004; Platonov et al. 1997, 1998). Patients with the Fc $\gamma$ RIIa-H/H131 allotype have been reported to have higher antibody-mediated phagocytosis-dependent resistance to IMD compared to patients carrying the Fc $\gamma$ RIIa-R/R131 allotype and were less likely to develop severe IMD (Platonov et al. 1997, 1998). There have also been conflicting studies showing no association between Fc $\gamma$ RIIa p.H131R and IMD (Smith et al. 2003; van der Pol et al. 2001). Fc $\gamma$ RIIIa is expressed on monocytes, macrophages and natural killer cells, and can bind IgG1, IgG3, and IgG4. There are two allotypes determined by FCGR3A rs396991 (p.V158F), with the V158 allotype able to increase binding of IgG (Koene et al. 1997). Finally, FcyRIIIb is expressed on neutrophils and binds IgG1, and IgG3. Fc $\gamma$ RIIIb contains a neutrophil antigen polymorphism (NA1/NA2), attributed to a group of five base substitutions, with Fc $\gamma$ RIIIb-NA1 shown to bind more efficiently than FcyRIIIa-NA2 (van der Pol et al. 2001). FcyRIIIb polymorphism alone is not associated with IMD but a combination of homozygous polymorphisms of all three Fc $\gamma \mathrm{Rs}$ is observed in candidate gene studies to be significantly increased in relatives of IMD patients (Smith et al. 2003; van der Pol et al. 2001). Furthermore, a homozygous combination of $F C G R 2 A$ p.H131R and FCGR3B NA2 was reported in a Dutch cohort of terminal complement deficient families to be associated with IMD (Table 2) (Fijen et al. 2000).

\section{Coagulation and fibrinolysis}

Circulating meningococcal endotoxin is a strong activator of the coagulation pathway causing generation of thrombin (Lecuyer et al. 2017). Coagulopathy is a feature of severe IMD, resulting in meningococcal shock which can lead to the most severe complication, purpura fulminans, developing in 15-20\% of cases (Kondaveeti et al. 1999; Powars et al. 1993). Purpura fulminans is primarily a thrombotic disorder that is characterised by widespread intravascular thrombosis and haemorrhagic lesions that can progress into skin necrosis requiring grafting or amputations (Kondaveeti et al. 1999; Lecuyer et al. 2017; Powars et al. 1993). The fibrinolytic system can regulate the coagulation response but polymorphisms in genes that are part of coagulation and fibrinolysis can deregulate this interaction and result in IMD (Lecuyer et al. 2017). Most candidate gene studies of genes involved in this pathway investigate the severity of IMD by comparing more severe manifestations of IMD, such as death or purpura fulminans, against non-severe IMD. The factor $\mathrm{V}$ Leiden mutation $\left(\mathrm{FV}^{\mathrm{L}}\right)$, a SNP in $F 5$ rs6025, is associated with thrombotic events (Kondaveeti et al. 1999). This polymorphism also results in resistance to activated protein $\mathrm{C}$, a key anti-coagulant that can inhibit plasminogen activator inhibitor (PAI) and deactivate factor $\mathrm{V}$, and factor VIII, to downregulate a pro-coagulation signalling cascade. The $\mathrm{FV}^{\mathrm{L}}$ mutation has been associated with development of severe purpura fulminans in IMD as a homozygous mutation in a single case study and as a heterozygous mutation in a large paediatric cohort candidate gene study (Table 2) (Kondaveeti et al. 1999; Sackesen et al. 1998). Protein C, encoded by PROC gene, is activated by thrombin and in meningococcal septicaemia low protein $\mathrm{C}$ plasma levels are associated with increased disease severity (Brandtzaeg et al. 1989). Two SNPs, in the PROC 5'UTR promoter region (rs1799808 and rs1799809), are known to affect activated protein C plasma levels (Spek et al. 1995). In a candidate gene study, a specific PROC haplotype was associated with IMD (Table 2) (Binder et al. 2007b). Furthermore, the authors suggested that possession of the $\mathrm{CG}$ haplotype increased the risk of developing meningococcal septicaemia and that a homozygous TA haplotype conferred protection against meningococcal septicaemia (Table 2) (Binder et al. 2007b).

A polymorphism in thrombin activatable fibrinolysis inhibitor (TAFI), encoded by CPB2 gene, rs779491029, has been shown to increase its anti-fibrinolytic potential (Emonts et al. 2008). This candidate gene study demonstrated an association of the polymorphism with an increased risk of developing septicaemia and was observed in the parents of IMD fatalities (Table 2) (Emonts et al. 2008; Kremer Hovinga et al. 2004; Schneider et al. 2002). Furthermore, a $4 \mathrm{G} / 5 \mathrm{G}$ insertion/deletion polymorphism in the SERPINE1 promoter region was found to determine plasma PAI-1 levels and promotes severe coagulopathy, with high levels of PAI-1 associated with severe meningococcal septic shock and poor outcome of IMD (Table 2) (Binder et al. 2007a; Geishofer et al. 2005; Hermans et al. 1999; Westendorp et al. 1999). The 4G/4G genotype is associated with increased plasma PAI-1 levels and mortality in severe adult septicaemia (Lorente et al. 2015). A candidate gene study of the relatives of IMD patients reported that the homozygous $4 \mathrm{G}$ genotype was associated with meningococcal septic shock, whereas the $5 \mathrm{G}$ homozygous genotype was associated with meningococcal meningitis (Table 2) (Westendorp et al. 1999). However, a meta-analysis study has shown no association to be found between the SERPINE1 promoter polymorphism and sepsis susceptibility (Shi et al. 2015). 


\section{Conclusion}

There is strong evidence for a central role for host genetics in predisposition to meningococcal infection. Common polymorphisms, by dint of their frequency, may play a large role when the interaction between pathogen and host is considered at a population level. However, rare monogenic disorders are most significant for an individual, and they provide unprecedented insight into disease mechanisms. To date, mutations in genes involved in complement pathways continues to appear in all host genetic investigations of $\mathrm{Nm}$ infection, indicating a key role for complement in host defence against infection. Both rare monogenic traits, such as terminal complement deficiencies of $C 5-C 9, C F D$, $C F B, C F I$, and $C 3$, and common polymorphisms in the CFH/CFHR3 region have been found in association with IMD. The large majority of genes discussed in this review were discovered through candidate gene studies, and most findings require validation in larger studies. Furthermore, caution must be taken interpreting SNP findings that have not been validated in other populations as significant findings resulting from candidate gene studies may in part relate to haplotype variation between populations where SNPs are found. Candidate gene studies are being largely replaced by the more robust GWAS and large-scale sequencing studies. Future genetic studies may focus on meningococcal strainspecificity, elaborate on disease-outcome specific associations, and include a better understanding of the effect size(s) contributed by a single or combination of variants/mutations in IMD which can help in estimating clinical risk of developing IMD at the individual level. In the UK, the recent introduction of the $4 \mathrm{CMenB}$ vaccine has reduced but not eliminated IMD (Parikh et al. 2016); however, the efficacy in protecting those with underlying immunodeficiencies remains unknown (Gianchecchi et al. 2015). The most vulnerable patients who develop IMD may contribute to vaccine failures due to the nature of their immunodeficiencies as observed in invasive pneumococcal disease (Maglione et al. 2014). Hence, the significance of understanding the underlying genetics of IMD is as relevant as ever. Given the increasing availability of patient-based genetic sequencing, we propose that children who have had a single severe episode of IMD should be considered for genetic investigations. Currently, the authors are exploring whether detailed genetic investigations on a patient by patient basis is a useful adjunct to the follow-up care of patients with IMD. Identification of key pathways for protection against meningococcal infection will contribute vital knowledge to our understanding of the pathogenesis of IMD.

Acknowledgements The authors thank Dr Clive Hoggart and Dr Aubrey Cunnington for helpful discussions. We apologize to authors whose work could not be cited owing to space limitations.
Funding This work was supported by the National Institute for Health Research Imperial Biomedical Research Centre at Imperial College (Grant number P76547), and the European Union Seventh Framework Programme for Research and Technological Development (European Union Childhood Life-Threatening Infectious Disease Study [EUCLIDS] Grant Agreement 279185). V.S.-S. is funded by a UK Research and Innovation Future Leader's Fellowship (MR/S032304/1).

\section{Compliance with ethical standards}

Conflict of interest On behalf of all authors, the corresponding author states that there is no conflict of interest.

Open Access This article is licensed under a Creative Commons Attribution 4.0 International License, which permits use, sharing, adaptation, distribution and reproduction in any medium or format, as long as you give appropriate credit to the original author(s) and the source, provide a link to the Creative Commons licence, and indicate if changes were made. The images or other third party material in this article are included in the article's Creative Commons licence, unless indicated otherwise in a credit line to the material. If material is not included in the article's Creative Commons licence and your intended use is not permitted by statutory regulation or exceeds the permitted use, you will need to obtain permission directly from the copyright holder. To view a copy of this licence, visit http://creativecommons.org/licenses/by/4.0/.

\section{References}

Agier L, Deroubaix A, Martiny N, Yaka P, Djibo A, Broutin H (2013) Seasonality of meningitis in Africa and climate forcing: aerosols stand out. J R Soc Interface. https://doi.org/10.1098/ rsif.2012.0814

Alba-Dominguez M, Lopez-Lera A, Garrido S, Nozal P, GonzalezGranado I, Melero J, Soler-Palacin P, Camara C, Lopez-Trascasa M (2012) Complement factor I deficiency: a not so rare immune defect: characterization of new mutations and the first large gene deletion. Orphanet J Rare Dis 7:42. https://doi. org/10.1186/1750-1172-7-42

Arbour NC, Lorenz E, Schutte BC, Zabner J, Kline JN, Jones M, Frees K, Watt JL, Schwartz DA (2000) TLR4 mutations are associated with endotoxin hyporesponsiveness in humans. Nat Genet 25:187-191. https://doi.org/10.1038/76048

Arnold DF, Roberts AG, Thomas A, Ferry B, Morgan BP, Chapel H (2009) A novel mutation in a patient with a deficiency of the eighth component of complement associated with recurrent meningococcal meningitis. J Clin Immunol 29:691-695. https ://doi.org/10.1007/s10875-009-9295-7

Aycock WL, Mueller JH (1950) Meningococcus carrier rates and meningitis incidence. Bacteriol Rev 14:115-160

Balding J, Healy CM, Livingstone WJ, White B, Mynett-Johnson L, Cafferkey M, Smith OP (2003) Genomic polymorphic profiles in an Irish population with meningococcaemia: is it possible to predict severity and outcome of disease? Genes Immun 4:533-540. https://doi.org/10.1038/sj.gene.6364020

Barroso S, Sanchez B, Alvarez AJ, Lopez-Trascasa M, Lanuza A, Luque R, Wichmann I, Nunez-Roldan A (2004) Complement component C7 deficiency in two Spanish families. Immunology 113:518-523. https://doi.org/10.1111/j.1365-2567.2004.01997.x

Barroso S, Rieubland C, Jose alvarez A, Lopez-Trascasa M, Bart PA, Nunez-Roldan A, Sanchez B (2006) Molecular defects of the $\mathrm{C} 7$ gene in two patients with complement $\mathrm{C} 7$ 
deficiency. Immunology 118:257-260. https://doi.org/10.111 1/j.1365-2567.2006.02364.x

Barroso S, Lopez-Trascasa M, Merino D, Alvarez AJ, Nunez-Roldan A, Sanchez B (2010) C7 deficiency and meningococcal infection susceptibility in two spanish families. Scand J Immunol 72:3843. https://doi.org/10.1111/j.1365-3083.2010.02403.x

Biebl A, Muendlein A, Kazakbaeva Z, Heuberger S, Sonderegger G, Drexel H, Lau S, Nickel R, Kabesch M, Simma B (2009) CD14 C-159T and toll-like receptor 4 Asp299Gly polymorphisms in surviving meningococcal disease patients. PLoS ONE 4:e7374. https://doi.org/10.1371/journal.pone.0007374

Biesma DH, Hannema AJ, van Velzen-Blad H, Mulder L, van Zwieten R, Kluijt I, Roos D (2001) A family with complement factor D deficiency. J Clin Investig 108:233-240. https://doi.org/10.1172/ JCI12023

Binder A, Endler G, Muller M, Mannhalter C, Zenz W (2007) 4G4G genotype of the plasminogen activator inhibitor-1 promoter polymorphism associates with disseminated intravascular coagulation in children with systemic meningococcemia. J Thromb Haemost. https://doi.org/10.1111/j.1538-7836.2007.02724.x

Binder A, Endler G, Rieger S, Geishofer G, Resch B, Mannhalter C, Zenz W, Central European Meningococcal Genetic Study G (2007) Protein C promoter polymorphisms associate with sepsis in children with systemic meningococcemia. Hum Genet 122:183-190. https://doi.org/10.1007/s00439-007-0392-5

Bishof NA, Welch TR, Beischel LS (1990) C4B deficiency: a risk factor for bacteremia with encapsulated organisms. J Infect Dis 162:248-250. https://doi.org/10.1093/infdis/162.1.248

Braconier JH, Sjoholm AG, Soderstrom C (1983) Fulminant meningococcal infections in a family with inherited deficiency of properdin. Scand J Infect Dis 15:339-345. https://doi.org/10.3109/ inf.1983.15.issue-4.04

Bradley DT, Bourke TW, Fairley DJ, Borrow R, Shields MD, Zipfel PF, Hughes AE (2015) Susceptibility to invasive meningococcal disease: polymorphism of complement system genes and Neisseria meningitidis factor H binding protein. PLoS ONE 10:e0120757. https://doi.org/10.1371/journal.pone.0120757

Brandtzaeg P, Sandset PM, Joo GB, Ovstebo R, Abildgaard U, Kierulf $P$ (1989) The quantitative association of plasma endotoxin, antithrombin, protein $\mathrm{C}$, extrinsic pathway inhibitor and fibrinopeptide A in systemic meningococcal disease. Thromb Res 55:459-470. https://doi.org/10.1016/0049-3848(89)90054-6

Bredius RG, Derkx BH, Fijen CA, de Wit TP, de Haas M, Weening RS, van de Winkel JG, Out TA (1994) Fc gamma receptor IIa (CD32) polymorphism in fulminant meningococcal septic shock in children. J Infect Dis 170:848-853. https://doi.org/10.1093/ infdis/170.4.848

Brouwer MC, Read RC, van de Beek D (2010) Host genetics and outcome in meningococcal disease: a systematic review and metaanalysis. Lancet Infect Dis 10:262-274. https://doi.org/10.1016/ S1473-3099(10)70045-1

Caesar JJ, Lavender H, Ward PN, Exley RM, Eaton J, Chittock E, Malik TH, De Jorge GE, Pickering MC, Tang CM, Lea SM (2014) Competition between antagonistic complement factors for a single protein on $N$. meningitidis rules disease susceptibility. Elife. https://doi.org/10.7554/eLife.04008

Callaghan MJ, Rockett K, Banner C, Haralambous E, Betts H, Faust S, Maiden MC, Kroll JS, Levin M, Kwiatkowski DP, Pollard AJ (2008) Haplotypic diversity in human CEACAM genes: effects on susceptibility to meningococcal disease. Genes Immun 9:3037. https://doi.org/10.1038/sj.gene.6364442

Carbonnelle E, Helaine S, Nassif X, Pelicic V (2006) A systematic genetic analysis in Neisseria meningitidis defines the Pil proteins required for assembly, functionality, stabilization and export of type IV pili. Mol Microbiol 61:1510-1522. https:// doi.org/10.1111/j.1365-2958.2006.05341.x
Cartwright KAV, Stuart JM, Jones DM, Noah ND (1987) The Stonehouse survey: nasopharyngeal carriage of meningococci and Neisseria lactamica. Epidemiol Infect 99:591-601

Casanova JL (2015a) Human genetic basis of interindividual variability in the course of infection. Proc Natl Acad Sci USA 112:E7118-E7127. https://doi.org/10.1073/pnas.1521644112

Casanova JL (2015b) Severe infectious diseases of childhood as monogenic inborn errors of immunity. Proc Natl Acad Sci USA 112:E7128-E7137. https://doi.org/10.1073/pnas.1521651112

Cates KL, Densen P, Lockman JC, Levine RP (1992) C4B deficiency is not associated with meningitis or bacteremia with encapsulated bacteria. J Infect Dis 165:942-944. https://doi. org/10.1093/infdis/165.5.942

Caugant DA, Maiden MC (2009) Meningococcal carriage and disease-population biology and evolution. Vaccine 27(Suppl 2):B64-70. https://doi.org/10.1016/j.vaccine.2009.04.061

Caugant DA, Hoiby EA, Rosenqvist E, Froholm LO, Selander RK (1992) Transmission of Neisseria meningitidis among asymptomatic military recruits and antibody analysis. Epidemiol Infect 109:241-253. https://doi.org/10.1017/s09502688000501 96

Cohn AC, MacNeil JR, Clark TA, Ortega-Sanchez IR, Briere EZ, Meissner HC, Baker CJ, Messonnier NE, Centers for Disease C, Prevention (2013) Prevention and control of meningococcal disease: recommendations of the Advisory Committee on Immunization Practices (ACIP). MMWR Recomm Rep 62:1-28

Coureuil M, Join-Lambert O, Lecuyer H, Bourdoulous S, Marullo S, Nassif X (2012) Mechanism of meningeal invasion by Neisseria meningitidis. Virulence 3:164-172. https://doi.org/10.4161/ viru. 18639

Cunliffe NA, Snowden N, Dunbar EM, Haeney MR (1995) Recurrent meningococcal septicaemia and properdin deficiency. J Infect 31:67-68. https://doi.org/10.1016/s0163-4453(95)91550-8

Da Silva RE, Baracho GV, Sousa Lima A, Farah CS, Isaac L (2002) Homozygous hereditary C3 deficiency due to a premature stop codon. J Clin Immunol 22:321-330

Davila S, Wright VJ, Khor CC, Sim KS, Binder A, Breunis WB, Inwald D, Nadel S, Betts H, Carrol ED, de Groot R, Hermans PW, Hazelzet J, Emonts M, Lim CC, Kuijpers TW, Martinon-Torres F, Salas A, Zenz W, Levin M, Hibberd ML, International Meningococcal Genetics C (2010) Genome-wide association study identifies variants in the $\mathrm{CFH}$ region associated with host susceptibility to meningococcal disease. Nat Genet 42:772-776. https://doi. org/10.1038/ng.640

Delgado-Cervino E, Fontan G, Lopez-Trascasa M (2005) C5 complement deficiency in a Spanish family. Molecular characterization of the double mutation responsible for the defect. Mol Immunol 42:105-111. https://doi.org/10.1016/j.molimm.2004.06.036

Dellepiane RM, Dell'Era L, Pavesi P, Macor P, Giordano M, De Maso L, Pietrogrande MC, Cugno M (2016) Invasive meningococcal disease in three siblings with hereditary deficiency of the 8(th) component of complement: evidence for the importance of an early diagnosis. Orphanet J Rare Dis 11:64. https://doi. org/10.1186/s13023-016-0448-5

Densen P, Weiler JM, Griffiss JM, Hoffmann LG (1987) Familial properdin deficiency and fatal meningococcemia. Correction of the bactericidal defect by vaccination. N Engl J Med 316:922-926. https://doi.org/10.1056/NEJM198704093161506

Domingo P, Muniz-Diaz E, Baraldes MA, Arilla M, Barquet N, Pericas R, Juarez C, Madoz P, Vazquez G (2002) Associations between Fc gamma receptor IIA polymorphisms and the risk and prognosis of meningococcal disease. Am J Med 112:19-25. https:// doi.org/10.1016/s0002-9343(01)01047-6

Domingo P, Muniz-Diaz E, Baraldes MA, Arilla M, Barquet N, Pericas R, Juarez C, Madoz P, Vazquez G (2004) Relevance of genetically determined host factors to the prognosis of meningococcal 
disease. Eur J Clin Microbiol Infect Dis 23:634-637. https://doi. org/10.1007/s10096-004-1167-8

El Sissy C, Rosain J, Vieira-Martins P, Bordereau P, Gruber A, Devriese M, de Pontual L, Taha MK, Fieschi C, Picard C, Fremeaux-Bacchi V (2019) Clinical and genetic spectrum of a large cohort with total and sub-total complement deficiencies. Front Immunol 10:1936. https://doi.org/10.3389/fimmu.2019.01936

Emonts M, de Bruijne EL, Guimaraes AH, Declerck PJ, Leebeek FW, de Maat MP, Rijken DC, Hazelzet JA, Gils A (2008) Thrombin-activatable fibrinolysis inhibitor is associated with severity and outcome of severe meningococcal infection in children. J Thromb Haemost 6:268-276. https://doi.org/10.111 1/j.1538-7836.2007.02841.x

Endler G, Marculescu R, Starkl P, Binder A, Geishofer G, Muller M, Zohrer B, Resch B, Zenz W, Mannhalter C (2006) Polymorphisms in the interleukin-1 gene cluster in children and young adults with systemic meningococcemia. Clin Chem 52:511-514

Erickson L, De Wals P (1998) Complications and sequelae of meningococcal disease in Quebec, Canada, 1990-1994. Clin Infect Dis 26:1159-1164. https://doi.org/10.1086/520303

Faber J, Meyer CU, Gemmer C, Russo A, Finn A, Murdoch C, Zenz W, Mannhalter C, Zabel BU, Schmitt H, Habermehl P, Zepp F, Knuf M (2006) Human toll-like receptor 4 mutations are associated with susceptibility to invasive meningococcal disease in infancy. Pediatr Infect Dis J 25:80-81

Faber J, Schuessler T, Finn A, Murdoch C, Zenz W, Habermehl P, Meyer CU, Zabel BU, Schmitt H, Zepp F, Knuf M (2007) Agedependent association of human mannose-binding lectin mutations with susceptibility to invasive meningococcal disease in childhood. Pediatr Infect Dis J 26:243-246

Faber J, Henninger N, Finn A, Zenz W, Zepp F, Knuf M (2009) A toll-like receptor 4 variant is associated with fatal outcome in children with invasive meningococcal disease. Acta Paediatr 98:548-552. https://doi.org/10.1111/j.1651-2227.2008.01163.x

Fasano MB, Densen P, McLean RH, Winkelstein JA (1990) Prevalence of homozygous $\mathrm{C} 4 \mathrm{~B}$ deficiency in patients with deficiencies of terminal complement components and meningococcemia. J Infect Dis 162:1220-1221. https://doi.org/10.1093/infdi s/162.5.1220

Fernie BA, Orren A, Sheehan G, Schlesinger M, Hobart MJ (1997) Molecular bases of $\mathrm{C} 7$ deficiency: three different defects. J Immunol 159:1019-1026

Figueroa JE, Densen P (1991) Infectious diseases associated with complement deficiencies. Clin Microbiol Rev 4:359-395. https://doi. org $/ 10.1128 / \mathrm{cmr} .4 .3 .359$

Figueroa J, Andreoni J, Densen P (1993) Complement deficiency states and meningococcal disease. Immunol Res 12:295-311

Fijen CA, Kuijper EJ, Hannema AJ, Sjoholm AG, van Putten JP (1989) Complement deficiencies in patients over ten years old with meningococcal disease due to uncommon serogroups. Lancet 2:585-588. https://doi.org/10.1016/s0140-6736(89)90712-5

Fijen CA, Kuijper EJ, te Bulte MT, Daha MR, Dankert J (1999) Assessment of complement deficiency in patients with meningococcal disease in The Netherlands. Clin Infect Dis 28:98-105. https:// doi.org/10.1086/515075

Fijen CA, Bredius RG, Kuijper EJ, Out TA, De Haas M, De Wit AP, Daha MR, De Winkel JG (2000) The role of Fcgamma receptor polymorphisms and $\mathrm{C} 3$ in the immune defence against Neisseria meningitidis in complement-deficient individuals. Clin Exp Immunol 120:338-345. https://doi.org/10.104 6/j.1365-2249.2000.01208.x

Flexner S (1913) The results of the serum treatment in thirteen hundred cases of epidemic meningitis. J Exp Med 17:553-576

Flexner S, Jobling JW (1908) An analysis of four hundred cases of epidemic meningitis treated with the anti-meningitis serum. J Exp Med 10:690-733. https://doi.org/10.1084/jem.10.5.690
Frans G, Moens L, Schrijvers R, Wuyts G, Bouckaert B, Schaballie H, Dupont L, Bossuyt X, Corveleyn A, Meyts I (2015) PID in disguise: molecular diagnosis of IRAK-4 deficiency in an adult previously misdiagnosed with autosomal dominant hyper IgE syndrome. J Clin Immunol 35:739-744. https://doi.org/10.1007/ s10875-015-0205-X

Fredrikson GN, Westberg J, Kuijper EJ, Tijssen CC, Sjoholm AG, Uhlen M, Truedsson L (1996) Molecular characterization of properdin deficiency type III: dysfunction produced by a single point mutation in exon 9 of the structural gene causing a tyrosine to aspartic acid interchange. J Immunol 157:3666-3671

Garred P, Michaelsen TE, Bjune G, Thiel S, Svejgaard A (1993) A low serum concentration of mannan-binding protein is not associated with serogroup B or C meningococcal disease. Scand J Immunol 37:468-470. https://doi.org/10.1111/j.1365-3083.1993.tb03320.x

Geishofer G, Binder A, Muller M, Zohrer B, Resch B, Muller W, Faber J, Finn A, Endler G, Mannhalter C, Zenz W, Central European Meningococcal Genetic Study G (2005) 4G/5G promoter polymorphism in the plasminogen-activator-inhibitor-1 gene in children with systemic meningococcaemia. Eur J Pediatr 164:486490. https://doi.org/10.1007/s00431-005-1673-4

Genel F, Atlihan F, Gulez N, Sjoholm AG, Skattum L, Truedsson L (2006) Properdin deficiency in a boy with fulminant meningococcal septic shock. Acta Paediatr 95:1498-1500. https://doi. org/10.1080/08035250600603008

Gianchecchi E, Torelli A, Piccini G, Piccirella S, Montomoli E (2015) Neisseria meningitidis infection: who, when and where? Expert Rev Anti Infect Ther 13:1249-1263. https://doi. org/10.1586/14787210.2015.1070096

Goldschneider I, Gotschlich EC, Artenstein MS (1969a) Human immunity to the meningococcus. I. the role of humoral antibodies. J Exp Med 129:1307-1326

Goldschneider I, Gotschlich EC, Artenstein MS (1969b) Human immunity to the meningococcus. II. Development of natural immunity. J Exp Med 129:1327-1348

Hack CE, De Groot ER, Felt-Bersma RJ, Nuijens JH, Strack Van Schijndel RJ, Eerenberg-Belmer AJ, Thijs LG, Aarden LA (1989) Increased plasma levels of interleukin-6 in sepsis. Blood 74:1704-1710

Hackett SJ, Thomson AP, Hart CA (2001) Cytokines, chemokines and other effector molecules involved in meningococcal disease. J Med Microbiol 50:847-859. https://doi. org/10.1099/0022-1317-50-10-847

Haralambous E, Weiss HA, Radalowicz A, Hibberd ML, Booy R, Levin M (2003) Sibling familial risk ratio of meningococcal disease in UK Caucasians. Epidemiol Infect 130:413-418. https ://doi.org/10.1017/s0950268803008513

Haralambous E, Dolly SO, Hibberd ML, Litt DJ, Udalova IA, O'Dwyer C, Langford PR, Simon Kroll J, Levin M (2006) Factor H, a regulator of complement activity, is a major determinant of meningococcal disease susceptibility in UK Caucasian patients. Scand J Infect Dis 38:764-771. https://doi.org/10.1080/00365 540600643203

Heesterbeek DA, Bardoel BW, Parsons ES, Bennett I, Ruyken M, Doorduijn DJ, Gorham RD Jr, Berends ET, Pyne AL, Hoogenboom BW, Rooijakkers SH (2019) Bacterial killing by complement requires membrane attack complex formation via surface-bound C5 convertases. EMBO J. https://doi.org/10.15252/embj.20189 9852

Helminen M, Seitsonen S, Jarva H, Meri S, Jarvela IE (2012) A novel mutation W388X underlying properdin deficiency in a Finnish family. Scand J Immunol 75:445-448. https://doi.org/10.111 1/j.1365-3083.2012.02674.x

Hermans PW, Hibberd ML, Booy R, Daramola O, Hazelzet JA, de Groot R, Levin M (1999) 4G/5G promoter polymorphism in the plasminogen-activator-inhibitor-1 gene and outcome of 
meningococcal disease. Meningococcal Research Group. Lancet 354:556-560. https://doi.org/10.1016/s0140-6736(99)02220-5

Hibberd ML, Sumiya M, Summerfield JA, Booy R, Levin M (1999) Association of variants of the gene for mannose-binding lectin with susceptibility to meningococcal disease. Meningococcal Research Group. Lancet 353:1049-1053. https://doi.org/10.1016/ s0140-6736(98)08350-0

Hiemstra PS, Langeler E, Compier B, Keepers Y, Leijh PC, van den Barselaar MT, Overbosch D, Daha MR (1989) Complete and partial deficiencies of complement factor D in a Dutch family. $\mathbf{J}$ Clin Investig 84:1957-1961. https://doi.org/10.1172/JCI114384

Hoare S, El-Shazali O, Clark JE, Fay A, Cant AJ (2002) Investigation for complement deficiency following meningococcal disease. Arch Dis Child 86:215-217. https://doi.org/10.1136/adc.86.3.215

Hobart MJ, Fernie BA, Fijen KA, Orren A (1998) The molecular basis of C6 deficiency in the western Cape, South Africa. Hum Genet 103:506-512. https://doi.org/10.1007/s004390050858

Huppmann AR, Leiding JW, Hsu AP, Raffeld M, Uzel G, Pittaluga S, Holland SM (2015) Pathologic findings in NEMO deficiency: a surgical and autopsy survey. Pediatr Dev Pathol 18:387-400. https://doi.org/10.2350/15-05-1631-OA.1

Hussain A, Prasad KS, Bhattacharyya D, El-Bouri K (2007) C2 deficiency primary meningococcal arthritis of the elbow by Neisseria meningitidis serogroup $\mathrm{Y}$ in a 12-year old girl. Infection 35:287-288. https://doi.org/10.1007/s15010-007-3039-5

Jack DL, Cole J, Naylor SC, Borrow R, Kaczmarski EB, Klein NJ, Read RC (2006) Genetic polymorphism of the binding domain of surfactant protein-A2 increases susceptibility to meningococcal disease. Clin Infect Dis 43:1426-1433. https://doi. org/10.1086/508775

Janeway CAJ, Travers P, Walport M et al (2001) The complement system and innate immunity. Immunobiology: the immune system in health and disease. Garland Science, New York

Jonsson G, Truedsson L, Sturfelt G, Oxelius VA, Braconier JH, Sjoholm AG (2005) Hereditary C2 deficiency in Sweden: frequent occurrence of invasive infection, atherosclerosis, and rheumatic disease. Medicine (Baltimore) 84:23-34. https://doi. org/10.1097/01.md.0000152371.22747.1e

Kaufmann T, Hansch G, Rittner C, Spath P, Tedesco F, Schneider PM (1993) Genetic basis of human complement C8 beta deficiency. J Immunol 150:4943-4947

Kawai T, Akira S (2011) Toll-like receptors and their crosstalk with other innate receptors in infection and immunity. Immunity 34:637-650. https://doi.org/10.1016/j.immuni.2011.05.006

Ki CS, Kim JW, Kim HJ, Choi SM, Ha GY, Kang HJ, Kim WD (2005) Two novel mutations in the $\mathrm{C} 7$ gene in a Korean patient with complement C7 deficiency. J Korean Med Sci 20:220-224. https ://doi.org/10.3346/jkms.2005.20.2.220

Kira R, Ihara K, Takada H, Gondo K, Hara T (1998) Nonsense mutation in exon 4 of human complement $\mathrm{C} 9$ gene is the major cause of Japanese complement C9 deficiency. Hum Genet 102:605610. https://doi.org/10.1007/s004390050749

Kirsch EA, Barton RP, Kitchen L, Giroir BP (1996) Pathophysiology, treatment and outcome of meningococcemia: a review and recent experience. Pediatr Infect Dis J 15:967-978 (quiz 979)

Koene HR, Kleijer M, Algra J, Roos D, von dem Borne AE, de Haas M (1997) Fc gammaRIIIa-158V/F polymorphism influences the binding of IgG by natural killer cell Fc gammaRIIIa, independently of the Fc gammaRIIIa-48L/R/H phenotype. Blood 90:1109-1114

Kojima T, Horiuchi T, Nishizaka H, Fukumori Y, Amano T, Nagasawa K, Niho Y, Hayashi K (1998) Genetic basis of human complement C8 alpha-gamma deficiency. J Immunol 161:3762-3766

Kondaveeti S, Hibberd ML, Booy R, Nadel S, Levin M (1999) Effect of the Factor V Leiden mutation on the severity of meningococcal disease. Pediatr Infect Dis J 18:893-896
Kremer Hovinga JA, Franco RF, Zago MA, Ten Cate H, Westendorp RG, Reitsma PH (2004) A functional single nucleotide polymorphism in the thrombin-activatable fibrinolysis inhibitor (TAFI) gene associates with outcome of meningococcal disease. J Thromb Haemost 2:54-57

$\mathrm{Ku}$ CL, Picard C, Erdos M, Jeurissen A, Bustamante J, Puel A, von Bernuth H, Filipe-Santos O, Chang HH, Lawrence T, Raes M, Marodi L, Bossuyt X, Casanova JL (2007) IRAK4 and NEMO mutations in otherwise healthy children with recurrent invasive pneumococcal disease. J Med Genet 44:16-23. https://doi. org/10.1136/jmg.2006.044446

Laver JR, Hughes SE, Read RC (2015) Neisserial molecular adaptations to the nasopharyngeal niche. Adv Microb Physiol 66:323355. https://doi.org/10.1016/bs.ampbs.2015.05.001

Lecuyer H, Borgel D, Nassif X, Coureuil M (2017) Pathogenesis of meningococcal purpura fulminans. Pathog Dis. https://doi. org/10.1093/femspd/ftx027

Lee TJ, Utsinger PD, Snyderman R, Yount WJ, Sparling PF (1978) Familial deficiency of the seventh component of complement associated with recurrent bacteremic infections due to Neisseria. J Infect Dis 138:359-368. https://doi.org/10.1093/infdi s/138.3.359

Lewis LA, Ram S (2014) Meningococcal disease and the complement system. Virulence 5:98-126. https://doi.org/10.4161/viru.26515

Lim D, Gewurz A, Lint TF, Ghaze M, Sepheri B, Gewurz H (1976) Absence of the sixth component of complement in a patient with repeated episodes of meningococcal meningitis. J Pediatr 89:4247. https://doi.org/10.1016/s0022-3476(76)80924-9

Lorente L, Martin MM, Borreguero-Leon JM, Barrios Y, Sole-Violan J, Ferreres J, Labarta L, Diaz C, Jimenez A (2015) The 4G/4G genotype of PAI-1 polymorphism is associated with higher plasma PAI-1 concentrations and mortality in patients with severe sepsis. PLoS ONE 10:e0129565. https://doi.org/10.1371/ journal.pone.0129565

Lundbo LF, Sorensen HT, Clausen LN, Hollegaard MV, Hougaard DM, Konradsen HB, Harboe ZB, Norgaard M, Benfield T (2015) Mannose-binding lectin gene, MBL2, polymorphisms do not increase susceptibility to invasive meningococcal disease in a population of Danish children. Open Forum Infect Dis 2:ofv127. https://doi.org/10.1093/ofid/ofv127

Macedo AC, Isaac L (2016) Systemic lupus erythematosus and deficiencies of early components of the complement classical pathway. Front Immunol 7:55. https://doi.org/10.3389/fimmu 2016.00055

Maglione PJ, Simchoni N, Black S, Radigan L, Overbey JR, Bagiella E, Bussel JB, Bossuyt X, Casanova JL, Meyts I, Cerutti A, Picard C, Cunningham-Rundles C (2014) IRAK-4 and MyD88 deficiencies impair IgM responses against T-independent bacterial antigens. Blood 124:3561-3571. https://doi.org/10.1182/blood -2014-07-587824

Martinon-Torres F, Png E, Khor CC, Davila S, Wright VJ, Sim KS, Vega A, Fachal L, Inwald D, Nadel S, Carrol ED, MartinonTorres N, Alonso SM, Carracedo A, Morteruel E, Lopez-Bayon J, Torre AC, Monge CC, de Aguilar PA, Torne EE, MartinezPadilla MD, Martinon-Sanchez JM, Levin M, Hibberd ML, Salas A, Network E, UK Emc-, London Ecm-IC (2016) Natural resistance to meningococcal disease related to $\mathrm{CFH}$ loci: meta-analysis of genome-wide association studies. Sci Rep 6:35842. https://doi. org/10.1038/srep35842

Martinon-Torres F, Salas A, Rivero-Calle I, Cebey-Lopez M, PardoSeco J, Herberg JA, Boeddha NP, Klobassa DS, Secka F, Paulus S, de Groot R, Schlapbach LJ, Driessen GJ, Anderson ST, Emonts M, Zenz W, Carrol ED, Van der Flier M, Levin M, Consortium E (2018) Life-threatening infections in children in Europe (the EUCLIDS Project): a prospective cohort 
study. Lancet Child Adolesc Health 2:404-414. https://doi. org/10.1016/S2352-4642(18)30113-5

Marujo F, Costa LC, Duarte R, Brito MJ, Cordeiro A, Neves C, Neves JF (2019) Invasive meningococcal disease unraveling a novel mutation in the $\mathrm{C} 5$ gene in a portuguese family. Pediatr Infect Dis J 38:416-418. https://doi.org/10.1097/INF.00000 00000002149

Mashbat B, Bellos E, Hodeib S, Bidmos F, Thwaites RS, Lu Y, Wright V, Herberg J, Klobassa DS, Zenz W, Hansel TT, Nadel S, Langford PR, Schlapbach LJ, Li M, Redinbo M, Di YP, Levin M, Sancho-Shimizu V (2019) A rare mutation in SPLUNC1 underlies meningococcal disease affecting bacterial adherence and invasion. Clin Infect Dis. https://doi.org/10.1093/cid/ciz60010.1093/ cid/ciz600/5526731

Nadel S, Newport MJ, Booy R, Levin M (1996) Variation in the tumor necrosis factor-a gene promoter region may be associated with death from meningococcal disease. J Infect Dis 174:878-880

Nagata M, Hara T, Aoki T, Mizuno Y, Akeda H, Inaba S, Tsumoto K, Ueda K (1989) Inherited deficiency of ninth component of complement: an increased risk of meningococcal meningitis. J Pediatr 114:260-264. https://doi.org/10.1016/s0022-3476(89)80793 $-0$

Nielsen HE, Koch C (1987) Congenital properdin deficiency and meningococcal infection. Clin Immunol Immunopathol 44:134 139. https://doi.org/10.1016/0090-1229(87)90060-2

Nielsen HE, Koch C, Magnussen P, Lind I (1989) Complement deficiencies in selected groups of patients with meningococcal disease. Scand J Infect Dis 21:389-396. https://doi. org/10.3109/00365548909167442

Nishizaka H, Horiuchi T, Zhu ZB, Fukumori Y, Nagasawa K, Hayashi K, Krumdieck R, Cobbs CG, Higuchi M, Yasunaga S, Niho Y, Volanakis JE (1996a) Molecular bases for inherited human complement component C6 deficiency in two unrelated individuals. J Immunol 156:2309-2315

Nishizaka H, Horiuchi T, Zhu ZB, Fukumori Y, Volanakis JE (1996b) Genetic bases of human complement C7 deficiency. J Immunol 157:4239-4243

Omoleke SA, Alabi O, Shuaib F, Braka F, Tegegne SG, Umeh GC, Ticha JM, Onimisin A, Nsubuga P, Adamu U, Mohammed K, Onoka C, Alemu W (2018) Environmental, economic and socio-cultural risk factors of recurrent seasonal epidemics of cerebrospinal meningitis in Kebbi state, northwestern Nigeria: a qualitative approach. BMC Public Health 18:1318. https://doi. org/10.1186/s12889-018-6196-9

Owen EP, Wurzner R, Leisegang F, Rizkallah P, Whitelaw A, Simpson J, Thomas AD, Harris CL, Giles JL, Hellerud BC, Mollnes TE, Morgan BP, Potter PC, Orren A (2015) A complement C5 gene mutation, c.754G\%3eA:p.A252T, is common in the Western Cape, South Africa and found to be homozygous in seven percent of Black African meningococcal disease cases. Mol Immunol 64:170-176. https://doi.org/10.1016/j.molimm.2014.11.010

Pace D, Pollard AJ (2012) Meningococcal disease: clinical presentation and sequelae. Vaccine 30(Suppl 2):B3-9. https://doi. org/10.1016/j.vaccine.2011.12.062

Parham KL, Roberts A, Thomas A, Wurzner R, Henderson HE, Potter PC, Morgan BP, Orren A (2007) Prevalence of mutations leading to complete C6 deficiency (C6Q0) in the Western Cape, South Africa and detection of novel mutations leading to C6Q0 in an Irish family. Mol Immunol 44:2756-2760. https://doi. org/10.1016/j.molimm.2006.11.022

Parikh SR, Andrews NJ, Beebeejaun K, Campbell H, Ribeiro S, Ward C, White JM, Borrow R, Ramsay ME, Ladhani SN (2016) Effectiveness and impact of a reduced infant schedule of $4 \mathrm{CMenB}$ vaccine against group B meningococcal disease in England: a national observational cohort study. Lancet 388:2775-2782. https ://doi.org/10.1016/S0140-6736(16)31921-3
Parikh SR, Campbell H, Gray SJ, Beebeejaun K, Ribeiro S, Borrow R, Ramsay ME, Ladhani SN (2018) Epidemiology, clinical presentation, risk factors, intensive care admission and outcomes of invasive meningococcal disease in England, 2010-2015. Vaccine 36:3876-3881. https://doi.org/10.1016/j.vaccine.2018.02.038

Pathan N, Faust SN, Levin M (2003) Pathophysiology of meningococcal meningitis and septicaemia. Arch Dis Child 88:601-607. https://doi.org/10.1136/adc.88.7.601

Petersen BH, Graham JA, Brooks GF (1976) Human deficiency of the eighth component of complement. The requirement of $\mathrm{C} 8$ for serum Neisseria gonorrhoeae bactericidal activity. J Clin Invest 57:283-290. https://doi.org/10.1172/JCI108279

Pfarr N, Prawitt D, Kirschfink M, Schroff C, Knuf M, Habermehl P, Mannhardt W, Zepp F, Fairbrother WG, Loos M, Burge CB, Pohlenz J (2005) Linking C5 deficiency to an exonic splicing enhancer mutation. J Immunol 174:4172-4177. https://doi. org/10.4049/jimmunol.174.7.4172

Picard C, Puel A, Bonnet M, Ku C, Bustamante J, Yang K, Soudais C, Dupuis S, Feinberg J, Fieschi C, Elbim C, Hitchcock R, Lammas D, Davies G, Al-Ghonaium A, Al-Rayes H, Al-Jumaah S, Al-Hajjar S, Al-Mohsen IZ, Frayha HH, Rucker R, Hawn TR, Aderem A, Tufenkeji H, Haraguchi S, Day NK, Good RA, Gougerot-Pocidalo M, Ozinsky A, Casanova JL (2003) Pyogenic bacterial infections in humans with IRAK-4 deficiency. Science 299:2076-2079. https://doi.org/10.1126/science.1081902

Picard C, von Bernuth H, Ghandil P, Chrabieh M, Levy O, Arkwright PD, McDonald D, Geha RS, Takada H, Krause JC, Creech CB, Ku CL, Ehl S, Marodi L, Al-Muhsen S, Al-Hajjar S, AlGhonaium A, Day-Good NK, Holland SM, Gallin JI, Chapel H, Speert DP, Rodriguez-Gallego C, Colino E, Garty BZ, Roifman C, Hara T, Yoshikawa H, Nonoyama S, Domachowske J, Issekutz AC, Tang M, Smart J, Zitnik SE, Hoarau C, Kumararatne DS, Thrasher AJ, Davies EG, Bethune C, Sirvent N, de Ricaud D, Camcioglu Y, Vasconcelos J, Guedes M, Vitor AB, Rodrigo C, Almazan F, Mendez M, Arostegui JI, Alsina L, Fortuny C, Reichenbach J, Verbsky JW, Bossuyt X, Doffinger R, Abel L, Puel A, Casanova JL (2010) Clinical features and outcome of patients with IRAK-4 and MyD88 deficiency. Medicine (Baltimore) 89:403-425. https://doi.org/10.1097/MD.0b013e3181 fd 8 ec 3

Picard C, Casanova JL, Puel A (2011) Infectious diseases in patients with IRAK-4, MyD88, NEMO, or IkappaBalpha deficiency. Clin Microbiol Rev 24:490-497. https://doi.org/10.1128/CMR.00001 $-11$

Pikaar JC, Voorhout WF, van Golde LM, Verhoef J, Van Strijp JA, van Iwaarden JF (1995) Opsonic activities of surfactant proteins $\mathrm{A}$ and $\mathrm{D}$ in phagocytosis of gram-negative bacteria by alveolar macrophages. J Infect Dis 172:481-489. https://doi.org/10.1093/ infdis/172.2.481

Platonov AE, Beloborodov VB, Vershinina IV (1993) Meningococcal disease in patients with late complement component deficiency: studies in the U.S.S.R. Medicine (Baltimore) 72:374-392. https ://doi.org/10.1097/00005792-199311000-00002

Platonov AE, Shipulin GA, Vershinina IV, Dankert J, van de Winkel JG, Kuijper EJ (1997) Association of human FcgRIIa (CD32) polymorphism with susceptibility to and severity of meningococcal disease. J Infect Dis 27:746-750

Platonov AE, Kuijper EJ, Vershinina IV, Shipulin GA, Westerdaal N, Fijen CA, van de Winkel JG (1998) Meningococcal disease and polymorphism of FcgammaRIIa (CD32) in late complement component-deficient individuals. Clin Exp Immunol 111:97-101. https://doi.org/10.1046/j.1365-2249.1998.00484.x

Pouw RB, Brouwer MC, Geissler J, van Herpen LV, Zeerleder SS, Wuillemin WA, Wouters D, Kuijpers TW (2016) Complement factor H-related protein 3 serum levels are low compared to factor $\mathrm{H}$ and mainly determined by gene copy number variation in 
CFHR3. PLoS ONE 11:e0152164. https://doi.org/10.1371/journ al.pone. 0152164

Powars D, Larsen R, Johnson J, Hulbert T, Sun T, Patch MJ, Francis R, Chan L (1993) Epidemic meningococcemia and purpura fulminans with induced protein C deficiency. Clin Infect Dis 17:254-261. https://doi.org/10.1093/clinids/17.2.254

Read RC, Camp NJ, di Giovine FS, Borrow R, Kaczmarski EB, Chaudhary AGA, Fox AJ, Duff GW (2000) An interleukin-1 genotype is associated with fatal outcome of meningococcal disease. $\mathbf{J}$ Infect Dis 182:1557-1560. https://doi.org/10.1086/315889

Read RC, Pullin J, Gregory S, Borrow R, Kaczmarski EB, di Giovine FS, Dower SK, Cannings C, Wilson AG (2001) A functional polymorphism of toll-like receptor 4 is not associated with likelihood or severity of meningococcal disease. J Infect Dis 184:640 642. https://doi.org/10.1086/322798

Read RC, Cannings C, Naylor SC, Timms JM, Maheswaran R, Borrow R, Kaczmarski EB, Duff GW (2003) Variation within genes encoding interleukin-1 and the interleukin-1 receptor antagonist influence the severity of meningococcal disease. Ann Intern Med 138:534-541. https://doi.org/10.7326/0003-4819-138-7-20030 4010-00009

Read RC, Teare DM, Pridmore AC, Naylor SC, Timms JM, Kaczmarski EB, Borrow R, Wilson AG (2009) The tumor necrosis factor polymorphism TNF $(-308)$ is associated with susceptibility to meningococcal sepsis, but not with lethality. Crit Care Med 37:1237-1243. https://doi.org/10.1097/CCM.0b013e31819c39bc

Rosenstein NE, Perkins BA, Stephens DS, Popovic T, Hughes JM (2001) Meningococcal disease. N Engl J Med 344:1378-1388. https://doi.org/10.1056/NEJM200105033441807

Ross SC, Densen P (1984) Complement deficiency states and infection: epidemiology, pathogenesis and consequences of neisserial and other infections in an immune deficiency. Medicine (Baltimore) 63:243-273

Sackesen C, Secmeer G, Gurgey A, Kanra G, Ecevit Z, Ceyhan M, Bulun A, Kara A, Turkmen O, Parlak H (1998) Homozygous Factor V Leiden mutation in a child with meningococcal purpura fulminans. Pediatr Infect Dis J 17:87. https://doi. org/10.1097/00006454-199801000-00023

Sanders LA, Feldman RG, Voorhorst-Ogink MM, de Haas M, Rijkers GT, Capel PJ, Zegers BJ, van de Winkel JG (1995) Human immunoglobulin $\mathrm{G}(\mathrm{IgG}) \mathrm{Fc}$ receptor IIA (CD32) polymorphism and $\mathrm{IgG} 2$-mediated bacterial phagocytosis by neutrophils. Infect Immun 63:73-81

Sanders MS, van Well GT, Ouburg S, Lundberg PS, van Furth AM, Morre SA (2011) Single nucleotide polymorphisms in TLR9 are highly associated with susceptibility to bacterial meningitis in children. Clin Infect Dis 52:475-480. https://doi.org/10.1093/ cid/ciq155

Saucedo L, Ackermann L, Platonov AE, Gewurz A, Rakita RM, Densen P (1995) Delineation of additional genetic bases for C8 beta deficiency. Prevalence of null alleles and predominance of C-\%3eT transition in their genesis. J Immunol 155:5022-5028

Schlesinger M, Nave Z, Levy Y, Slater PE, Fishelson Z (1990) Prevalence of hereditary properdin, $\mathrm{C} 7$ and $\mathrm{C} 8$ deficiencies in patients with meningococcal infections. Clin Exp Immunol 81:423-427. https://doi.org/10.1111/j.1365-2249.1990.tb05350.x

Schlesinger M, Mashal U, Levy J, Fishelson Z (1993) Hereditary properdin deficiency in three families of Tunisian Jews. Acta Paediatr 82:744-747. https://doi.org/10.1111/j.1651-2227.1993.tb12550.x

Schneider M, Boffa M, Stewart R, Rahman M, Koschinsky M, Nesheim M (2002) Two naturally occurring variants of TAFI (Thr-325 and Ile-325) differ substantially with respect to thermal stability and antifibrinolytic activity of the enzyme. J Biol Chem 277:10211030. https://doi.org/10.1074/jbc.M104444200

Schneider MC, Prosser BE, Caesar JJ, Kugelberg E, Li S, Zhang Q, Quoraishi S, Lovett JE, Deane JE, Sim RB, Roversi P, Johnson
S, Tang CM, Lea SM (2009) Neisseria meningitidis recruits factor $\mathrm{H}$ using protein mimicry of host carbohydrates. Nature 458:890-893. https://doi.org/10.1038/nature07769

Shi C, Sui Z, Li L, Yang R (2015) No association of SERPINE1 -675 polymorphism with sepsis susceptibility: a meta-analysis. Medicine (Baltimore) 94:e1173. https://doi.org/10.1097/MD.00000 00000001173

Sjoholm AG, Braconier JH, Soderstrom C (1982) Properdin deficiency in a family with fulminant meningococcal infections. Clin Exp Immunol 50:291-297

Slade C, Bosco J, Unglik G, Bleasel K, Nagel M, Winship I (2013) Deficiency in complement factor B. N Engl J Med 369:16671669. https://doi.org/10.1056/NEJMc1306326

Smirnova I, Mann N, Dols A, Derkx HH, Hibberd ML, Levin M, Beutler B (2003) Assay of locus-specific genetic load implicates rare Toll-like receptor 4 mutations in meningococcal susceptibility. Proc Natl Acad Sci USA 100:6075-6080. https://doi. org/10.1073/pnas.1031605100

Smith I, Vedeler C, Halstensen A (2003) FcgammaRIIa and FcgammaRIIIb polymorphisms were not associated with meningococcal disease in Western Norway. Epidemiol Infect 130:193-199. https://doi.org/10.1017/s0950268802008087

Sng CCT, O'Byrne S, Prigozhin DM, Bauer MR, Harvey JC, Ruhle M, Challis BG, Lear S, Roberts LD, Workman S, Janowitz T, Magiera L, Doffinger R, Buckland MS, Jodrell DJ, Semple RK, Wilson TJ, Modis Y, Thaventhiran JED (2018) A type III complement factor D deficiency: structural insights for inhibition of the alternative pathway. J Allergy Clin Immunol 142(311-314):e6. https://doi.org/10.1016/j.jaci.2018.01.048

Snyderman R, Durack DT, McCarty GA, Ward FE, Meadows L (1979) Deficiency of the fifth component of complement in human subjects. Clinical, genetic and immunologic studies in a large kindred. Am J Med 67:638-645. https://doi.org/10.1016/00029343(79)90247-x

Spath PJ, Sjoholm AG, Fredrikson GN, Misiano G, Scherz R, Schaad UB, Uhring-Lambert B, Hauptmann G, Westberg J, Uhlen M, Wadelius C, Truedsson L (1999) Properdin deficiency in a large Swiss family: identification of a stop codon in the properdin gene, and association of meningococcal disease with lack of the IgG2 allotype marker G2m(n). Clin Exp Immunol 118:278-284. https://doi.org/10.1046/j.1365-2249.1999.01056.x

Spek CA, Greengard JS, Griffin JH, Bertina RM, Reitsma PH (1995) Two mutations in the promoter region of the human protein $\mathrm{C}$ gene both cause type I protein $\mathrm{C}$ deficiency by disruption of two HNF-3 binding sites. J Biol Chem 270:24216-24221. https://doi. org/10.1074/jbc.270.41.24216

Spinner MA, Sanchez LA, Hsu AP, Shaw PA, Zerbe CS, Calvo KR, Arthur DC, Gu W, Gould CM, Brewer CC, Cowen EW, Freeman AF, Olivier KN, Uzel G, Zelazny AM, Daub JR, Spalding CD, Claypool RJ, Giri NK, Alter BP, Mace EM, Orange JS, Cuellar-Rodriguez J, Hickstein DD, Holland SM (2014) GATA2 deficiency: a protean disorder of hematopoiesis, lymphatics, and immunity. Blood 123:809-821. https://doi.org/10.1182/blood -2013-07-515528

Sprong T, Roos D, Weemaes C, Neeleman C, Geesing CL, Mollnes TE, van Deuren M (2006) Deficient alternative complement pathway activation due to factor D deficiency by 2 novel mutations in the complement factor D gene in a family with meningococcal infections. Blood 107:4865-4870. https://doi.org/10.1182/blood $-2005-07-2820$

Stephens DS, Hoffman LH, McGee ZA (1983) Interaction of Neisseria meningitidis with human nasopharyngeal mucosa: attachment and entry into columnar epithelial cells. J Infect Dis 148:369376. https://doi.org/10.1093/infdis/148.3.369 
Tanaka T, Narazaki M, Kishimoto T (2014) IL-6 in inflammation, immunity, and disease. Cold Spring Harb Perspect Biol 6:a016295. https://doi.org/10.1101/cshperspect.a016295

Tebruegge M, Curtis N (2008) Epidemiology, etiology, pathogenesis, and diagnosis of recurrent bacterial meningitis. Clin Microbiol Rev 21:519-537. https://doi.org/10.1128/CMR.00009-08

Titmarsh CJ, Moscovis SM, Hall S, Tzanakaki G, Kesanopoulos K, Xirogianni A, Scott RJ, Blackwell CC (2013) Comparison of cytokine gene polymorphisms among Greek patients with invasive meningococcal disease or viral meningitis. J Med Microbiol 62:694-700. https://doi.org/10.1099/jmm.0.058073-0

van den Bogaard R, Fijen CA, Schipper MG, de Galan L, Kuijper EJ, Mannens MM (2000) Molecular characterisation of 10 Dutch properdin type I deficient families: mutation analysis and X-inactivation studies. Eur J Hum Genet 8:513-518. https://doi. org/10.1038/sj.ejhg.5200496

van der Pol W-L, Huizinga TWJ, Vidarsson G, van der Linden MW, Jansen MD, Keijsers V, Leppers-van de Straat FGJ, Westerdaal NAC, van de Winkel JGJ, Westendorp RG (2001) Relevance of Fcg receptor and interleukin-10 polymorphisms for meningococcal disease. J Infect Dis 184:1548-1555. https://doi. org/10.1086/324662

Virji M (2009) Pathogenic neisseriae: surface modulation, pathogenesis and infection control. Nat Rev Microbiol 7:274-286. https ://doi.org/10.1038/nrmicro2097

Virji M, Makepeace K, Ferguson DJ, Watt SM (1996) Carcinoembryonic antigens (CD66) on epithelial cells and neutrophils are receptors for Opa proteins of pathogenic neisseriae. Mol Microbiol 22:941-950. https://doi.org/10.104 6/j.1365-2958.1996.01551.x

von Bernuth H, Picard C, Jin Z, Pankla R, Xiao H, Ku CL, Chrabieh M, Mustapha IB, Ghandil P, Camcioglu Y, Vasconcelos J, Sirvent N, Guedes M, Vitor AB, Herrero-Mata MJ, Arostegui JI, Rodrigo C, Alsina L, Ruiz-Ortiz E, Juan M, Fortuny C, Yague J, Anton J, Pascal M, Chang HH, Janniere L, Rose Y, Garty BZ, Chapel H, Issekutz A, Marodi L, Rodriguez-Gallego C, Banchereau J, Abel L, Li X, Chaussabel D, Puel A, Casanova JL (2008) Pyogenic bacterial infections in humans with MyD88 deficiency. Science 321:691-696. https://doi.org/10.1126/science.1158298

Vyse TJ, Morley BJ, Bartok I, Theodoridis EL, Davies KA, Webster AD, Walport MJ (1996) The molecular basis of hereditary complement factor I deficiency. J Clin Investig 97:925-933. https:// doi.org/10.1172/JCI118515

Waage A, Halstensen A, Espevik T (1987) Association between tumour necrosis factor in serum and fatal outcome in patients with meningococcal disease. Lancet 1:355-357. https://doi. org/10.1016/s0140-6736(87)91728-4

Waage A, Brandtzaeg P, Halstensen A, Kierulf P, Espevik T (1989) The complex pattern of cytokines in serum from patients with meningococcal septic shock. Association between interleukin 6, interleukin 1, and fatal outcome. J Exp Med 169:333-338. https ://doi.org/10.1084/jem.169.1.333
Wang X, Fleischer DT, Whitehead WT, Haviland DL, Rosenfeld SI, Leddy JP, Snyderman R, Wetsel RA (1995) Inherited human complement C5 deficiency. Nonsense mutations in exons 1 (Gln1 to Stop) and 36 (Arg 1458 to Stop) and compound heterozygosity in three African-American families. J Immunol 154:5464-5471

Welsch JA, Granoff D (2007) Immunity to Neisseria meningitidis group B in adults despite lack of serum bactericidal antibody. Clin Vaccine Immunol 14:1596-1602. https://doi.org/10.1128/ CVI.00341-07

Westberg J, Fredrikson GN, Truedsson L, Sjoholm AG, Uhlen M (1995) Sequence-based analysis of properdin deficiency: identification of point mutations in two phenotypic forms of an X-linked immunodeficiency. Genomics 29:1-8. https://doi.org/10.1006/ geno.1995.1208

Westendorp RG, Langermans JA, Huizinga TW, Elouali AH, Verweij CL, Boomsma DI, Vandenbroucke JP (1997) Genetic influence on cytokine production and fatal meningococcal disease. Lancet 349:170-173. https://doi.org/10.1016/s0140-6736(96)06413-6

Westendorp RG, Hottenga JJ, Slagboom PE (1999) Variation in plasminogen-activator-inhibitor-1 gene and risk of meningococcal septic shock. Lancet 354:561-563. https://doi.org/10.1016/S0140 -6736(98)09376-3

Wright V, Hibberd M, Levin M (2009) Genetic polymorphisms in host response to meningococcal infection: the role of susceptibility and severity genes. Vaccine 27(Suppl 2):B90-102. https://doi. org/10.1016/j.vaccine.2009.05.002

Wurzner R, Hobart MJ, Fernie BA, Mewar D, Potter PC, Orren A, Lachmann PJ (1995) Molecular basis of subtotal complement C6 deficiency. A carboxy-terminally truncated but functionally active C6. J Clin Investig 95:1877-1883. https://doi.org/10.1172/ JCI117868

Xie O, Pollard AJ, Mueller JE, Norheim G (2013) Emergence of serogroup X meningococcal disease in Africa: need for a vaccine. Vaccine 31:2852-2861. https://doi.org/10.1016/j.vacci ne.2013.04.036

Yazdankhah SP, Caugant DA (2004) Neisseria meningitidis: an overview of the carriage state. J Med Microbiol 53:821-832. https:// doi.org/10.1099/jmm.0.45529-0

Zhu ZB, Totemchokchyakarn K, Atkinson TP, Volanakis JE (1998) Molecular defects leading to human complement component C6 deficiency in an African-American family. Clin Exp Immunol 111:91-96. https://doi.org/10.1046/j.1365-2249.1998.00455.x

Zoppi M, Weiss M, Nydegger UE, Hess T, Spath PJ (1990) Recurrent meningitis in a patient with congenital deficiency of the $\mathrm{C} 9$ component of complement. First case of C9 deficiency in Europe. Arch Intern Med 150:2395-2399

Publisher's Note Springer Nature remains neutral with regard to jurisdictional claims in published maps and institutional affiliations. 